\title{
Estratégias de Hand-off com Balanceamento de Carga para Computação Móvel
}

Alessandro Santiago dos Santos

\author{
DisSERTAÇÃO APRESENTAdA AO \\ Instituto DE MATEMÁticA E EstatísticA DA \\ UNIVERSidAdE DE SÃo PAUlo \\ PARA OBTENÇÃO DO GRAU DE \\ Mestre em CiênCia da Computação.
}

Área de Concentração: Computação Móvel Orientador: Prof. Dr. Alfredo Goldman vel Lejbman

- São Paulo, SP - Março de 2003 - 


\title{
Estratégias de Hand-off com Balanceamento de Carga para Computação Móvel
}

\author{
Este exemplar corresponde à redação final \\ da dissertação devidamente corrigida e \\ defendida por Alessandro Santiago dos Santos \\ e aprovada pela comissão julgadora.
}

São Paulo, Março de 2003.

Banca Examinadora:

- Prof. Dr. Alfredo Goldman vel Lejbman (Orientador) - DCC-IME-USP

- Prof. Dr. Gerson Geraldo H. Cavalheiro - Unisinos-RS

- Prof. Dr. Marco Dimas Gubitoso - DCC-IME-USP 
À minha esposa Sandra e família. 


\section{Agradecimentos}

À Deus, que me deu forças, discernimento, equilíbrio e confiança para processeguir meus estudos, frente a tantos desafios intelectuais, culturais, e econômicos.

A todos aqueles que contribuíram diretamente no meu trabalho:

Ao Alfredo Goldman, pela confiança em mim e pela ótima orientação, sempre com muita dedicação, paciência, estímulo, exigência e persistência para tornar o trabalho cada vez melhor. E acima de tudo, não só meu orientador, mais também um grande amigo.

Aos Professores da banca examinadora, Gerson Cavalheiro e Marco Gubitoso, que com suas críticas sempre construtivas, foram fundamentais para aumentar a qualidade da dissertação.

A todos aqueles que contribuíram indiretamente no meu trabalho:

Ao Mateus, a Bianka, o Leandro, o Francisco, o Weslley, a Rosianni, e todos os outros que sempre me ajudaram no que foi preciso e possível, além de toda amizade que construímos durante este período.

Ao Markus Endler, Fabio Kon, e todos os demais docentes que ajudaram seja de forma específica no trabalho, seja com a ampliação dos meus conhecimentos na área, ou incentivandome sempre que possível.

A Diretoria da Rosch Administradora, principalmento o Sr. Jose Roberto Schmaltz, que possibilitou a minha transferência de Cuiabá-MT, para a cidade de São Paulo, com o intuito de possibilitar a realização do meu mestrado. Além disso, através do meu trabalho nesta empresa, foi possível manter-me financeiramente durante o início do mestrado na USP.

À minha esposa Sandra, que sempre acreditou em mim, e mesmo ficando longe (fisicamente) de mim durante o primeiro ano do mestrado, sempre foi minha companheira, e me ajudando e me dando forças para que eu fosse em frente.

À minha família: meu falecido pai, minha mãe, e irmãos, que sempre me apoiaram e ajudaram no que foi preciso, e a todos que torceram e torcem por mim. 


\begin{abstract}
In a mobile computing environment, the mobile devices communicate by radio with base stations, which are connected to wired networks. A process called channel allocation provides ways to connect mobile devices to the network.

The Radio Base Station broadcasts its signal on a geographical area, this area is denoted cell. A region may have many base stations, and there may be overlapping cells, that is, areas covered by more than one base station.

When a mobile device crosses the border of two adjacent cells, it starts a process called handoff, this process negociates the transition of this device from the current base station to the new base station. Many works on mobile computing do not consider the area of the overllaping cells. However, there are areas where a mobile device may be able to obtain enough signal of good quality from two or more base stations. We suggest new policies for the hand-off, where the decision to transfer a mobile device, in an area of overllaping cells, may also be started by the base stations.

This work presents some policies to do the distribution of the active mobile devices among the base stations, in order to better use the available resources.
\end{abstract}




\section{Resumo}

Em um ambiente tradicional de Computação Móvel, as unidades móveis se comunicam através de comunicação sem fio com bases, que por sua vez estão ligadas à rede fixa. Um processo denominado alocação de canais disponibiliza recursos para que uma unidade móvel possa se conectar a rede.

Uma célula é uma área geográfica atendida por um transmissor, ou melhor, por uma estação base de rádio. Em uma região podem ser instaladas mais de uma estação, ocasionando a sobreposição de células.

Quando uma unidade em movimento atravessa a região de fronteira entre estações base adjacentes, ela ativa um processo chamado hand-off, que negocia a transição desta unidade para a nova base. Em grande parte dos trabalhos da literatura, as áreas de cobertura das bases são consideradas disjuntas. Entretanto, existem áreas de intersecção onde sinais de mais de uma base estão disponíveis. Nós propomos novas políticas onde o hand-off também pode ser realizado por iniciativa das bases, ou seja, a decisão de transferir uma unidade móvel, em uma área de intersecção, também fica a cargo da base que está responsável por ela.

Este trabalho apresenta algumas estratégias para repartir as unidades móveis ativas em áreas de intersecção entre as bases, de forma a aproveitar melhor os recursos disponíveis. 


\section{Sumário}

\section{Introdução}

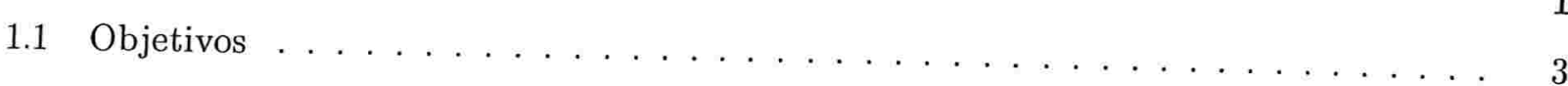

1.2 Organização do texto . . . . . . . . . . . . . . . 3

\section{Os Canais}

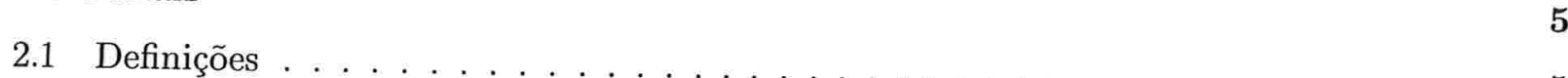

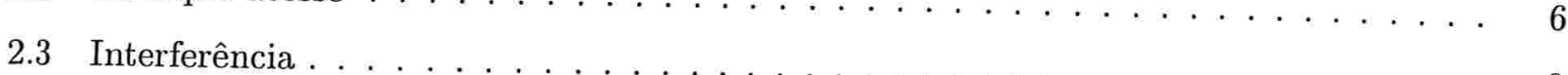

2.4 Planejamento dos canais . . . . . . . . . . . . . . . 8

3 Alocação de Canais 12

3.1 Definições . . . . . . . . . . . . . . . . . . . . . . . 12

3.2 Alocação fixa . . . . . . . . . . . . . . . . . . . . 13

3.3 Alocação dinâmica . . . . . . . . . . . . . . . . . . . . . . . 14

3.4 Alocação híbrida . . . . . . . . . . . . . . . . . . . . . 16

3.5 Hand-off . . . . . . . . . . . . . . . . . . . . . . 16

3.6 Reserva de canais . . . . . . . . . . . . . . . . . . 16

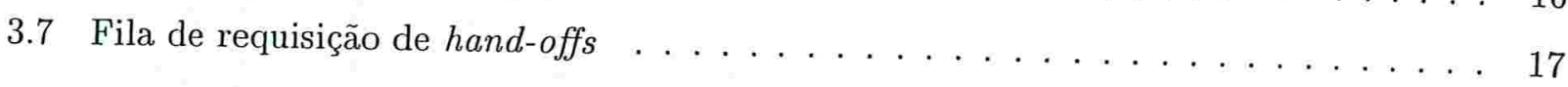

4 Trabalhos Relacionados à Intersecção de Células 18

4.1 Considerações iniciais . . . . . . . . . . . . . . . . . . 18

4.2 Handover seletivo para distribuição de tráfego em comunicações móveis . . . . . . . 19

4.3 Esquema de reserva de canais adaptativo . . . . . . . . . . . . . 21

4.4 Análise dos trabalhos . . . . . . . . . . . . . . . . . . . . . . 23 


\section{Modelo Sugerido}

5.1 Considerações iniciais $\ldots \ldots$

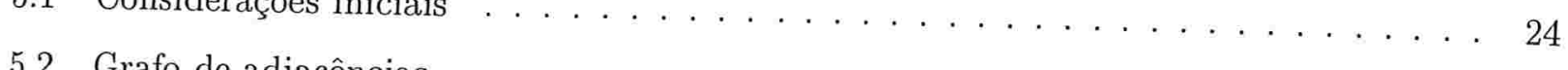

5.2 Grafo de adjacências . . . . . . . . . . . . . . . . . . . 26

5.3 Balanceamento de carga . . . . . . . . . . . . . . . . . . . 29

5.4 Comparação das estratégias . . . . . . . . . . . . . . . 33

6 A Mobilidade 34

6.1 Necessidade de padrões de mobilidade . . . . . . . . . . . . . . 34

6.2 Modelo de mobilidade genérico . . . . . . . . . . . . . . . 35

6.3 Modelos de mobilidade . . . . . . . . . . . . . . . . . 37

7 O Simulador $\quad 42$

7.1 Avaliação inicial . . . . . . . . . . . . . . . . . . . . 42

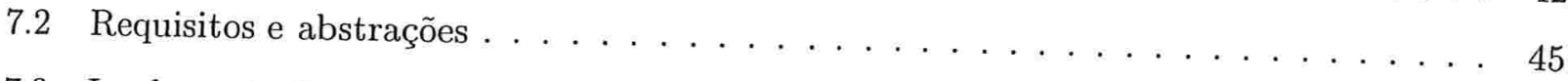

7.3 Implementação . . . . . . . . . . . . . . . . . . . 48

8 Simulação $\quad \mathbf{5 4}$

8.1 Parâmetros de avaliação . . . . . . . . . . . . . . . . . . . 54

8.2 Preparação do ambiente . . . . . . . . . . . . . . . . . . 55

8.3 Parâmetros de configuração da simulação . . . . . . . . . . . . . . . . 56

8.4 Avaliação dos resultados . . . . . . . . . . . . . . . . . . . . 59

8.5 Principais dificuldades e experiências adquiridas . . . . . . . . . . . 67

9 Considerações finais $\quad 69$

$\begin{array}{ll}\text { A Diagrama de Classes } & 71\end{array}$ 


\section{Lista de Figuras}

1.1 Ambiente de computação móvel.

2.1 Múltiplo Acesso por Divisão de Freqüência (FDMA). . . . . . . . . . . . . . . 7

2.2 Múltiplo Acesso por Divisão de Tempo (TDMA). . . . . . . . . . . . . 7

2.3 Múltiplo Acesso por Divisão de Código (CDMA). . . . . . . . . . . . . . . 8

2.4 Esquema com reuso de canais, com fator igual a $7 \ldots \ldots \ldots \ldots$

2.5 Diagrama de comunicação de uma unidade móvel. . . . . . . . . . . . . . 11

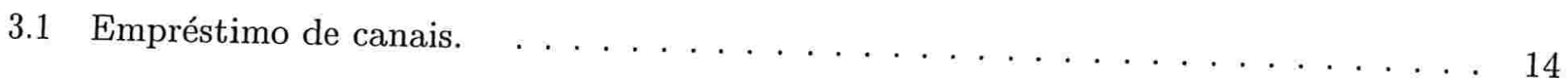

4.1 Princípio de funcionamento do esquema de Handover seletivo. . . . . . . . . . . . . 20

4.2 Reserva de canais para hand-off por mecanismo de limite de sinal. . . . . . . . . . . 22

5.1 Diagrama de nível de sinal no modelo tradicional . . . . . . . . . . . 25

5.2 Unidade móvel com trajetória tangente. . . . . . . . . . . . . . . 25

5.3 Diagrama de nível de sinal no modelo com intersecção. . . . . . . . . . . . . . 26

5.4 Distribuição da área de abrangência de ERBs adjacentes. . . . . . . . . . . . . 27

5.5 Representação das relações de adjacência entre regiões e ERBs por um grafo bipartido. 27

6.1 Representação de modelo genérico.

6.2 Modelo de mobilidade multidimensional baseado em perfis. . . . . . . . . . . 38

7.1 Representação dos componentes em módulos do sistema. . . . . . . . . . . . . . . 46

8.1 Gráfico das diferenças de desvio padrão de carga $(5$ a $70 \%)$. . . . . . . . . . . . 60

8.2 Gráfico das diferenças de desvio padrão de carga (80 a 100\%) . . . . . . . . . . . 61

8.3 Tráfego adicional por Faixa de Carga (\% de hand-offs adicionais). . . . . . . . . . . 62

8.4 Quantidade de novas conexões no sistema. . . . . . . . . . . . . . . . 65 
8.5 Tráfego adicional (\%hand-offs adicionais) 


\section{Lista de Tabelas}

3.1 Comparação entre estratégias de alocação fixa de canais. . . . . . . . . . . . . . . 14

3.2 Comparação entre Estratégias de alocação dinâmica de canais. . . . . . . . . . . . 15

4.1 Comparação dos algoritmos propostos em [15] . . . . . . . . . . . . . 21

5.1 Níveis de sinal. . . . . . . . . . . . . . . . . . . . . . 27

5.2 Comparação das formas de criação do grafo de adjacência. . . . . . . . . . . . 28

6.1 Zonas temporais . . . . . . . . . . . . . . . . . . 39

6.2 Probabilidade dos perfis de mobilidade para os usuários residênciais. . . . . . . . . 40

6.3 Probabilidades dos perfis de mobilidade para os usuários trabalhadores. . . . . . . . 41

7.1 Comparação entre diferentes simuladores. . . . . . . . . . . . . . . . . 44

7.2 Propagação do sinal de uma ERB.

7.3 Percentual populacional de unidades móveis. . . . . . . . . . . . . . . . . 49

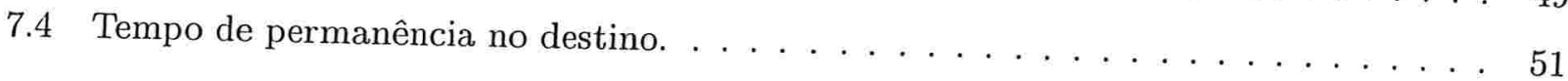

8.1 Quantidades de UMs no sistema. . . . . . . . . . . . . . . . . . . 57

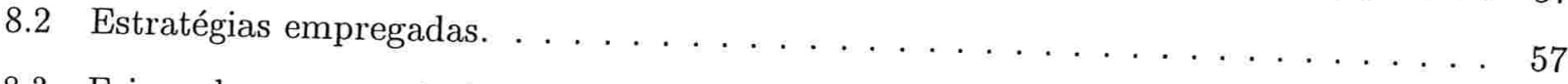

8.3 Faixas de percentuais de atuação. . . . . . . . . . . . . . . . . . . 58

8.4 Eventos geradores. . . . . . . . . . . . . . . . . . . . 58

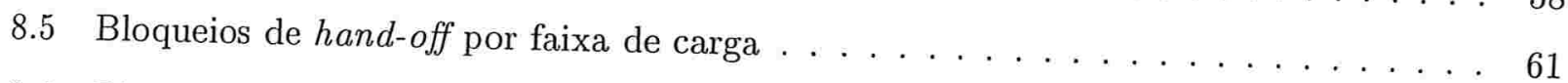

8.6 Bloqueios de hand-off com intervalos de confiança. . . . . . . . . . . . . 63

8.7 Quantidade de bits transmitidos com intervalos de confiança. . . . . . . . . . . 64

8.8 Quantidade total de simulações . . . . . . . . . . . . . . . . . 68 


\section{Capítulo 1}

\section{Introdução}

Nos últimos anos os avanços na área de computação móvel superaram muitas expectativas. O aumento de potencial e popularidade dos dispositivos portáteis (PDAs, palmtops, e hand-helds), a grande ascensão das telecomunicações, incluindo a grande utilização de redes celulares, foram alguns dos motivos que alavancaram este processo. Novos tipos de redes de celulares emergem com cada vez mais recursos, no entanto cada vez mais usuários estão se integrando a esta tecnologia, exigindo novas técnicas para otimizar a utilização destes recursos.

O conceito de comunicação sem fio está ligado ao fato de não haver ligação física entre os dispositivos envolvidos na comunicação, sendo esta feita através de ondas eletromagnéticas que trafegam pelo espaço.

A denominação Computação Móvel, ou Computação Nômade, se dá ao ambiente de computação onde os dispositivos móveis se comunicam com a parte fixa da rede através de comunicação sem fio [24]. A computação móvel amplia o conceito tradicional da computação distribuída. Um sistema distribuído com computadores móveis consiste em uma infra-estrutura fixa que está interligada a uma parte móvel (Figura 1.1).

A computação móvel provoca mudanças na forma de trabalho dos sistemas distribuídos, os quais possuem alguns fatores de influência, como os quais apresentados a seguir:

- Mobilidade: Introduz restrições inexistentes na computação fixa tradicional, favoráveis ou não, que influenciam o ambiente. A capacidade de movimentação de uma unidade móvel durante a comunicação com a rede fixa provoca mudança na forma como as informações devem ser vistas. Certas configurações do ambiente tradicional passam agora para um ambiente dinâmico, exigindo maior flexibilidade por parte destas configurações. Uma das novas características 


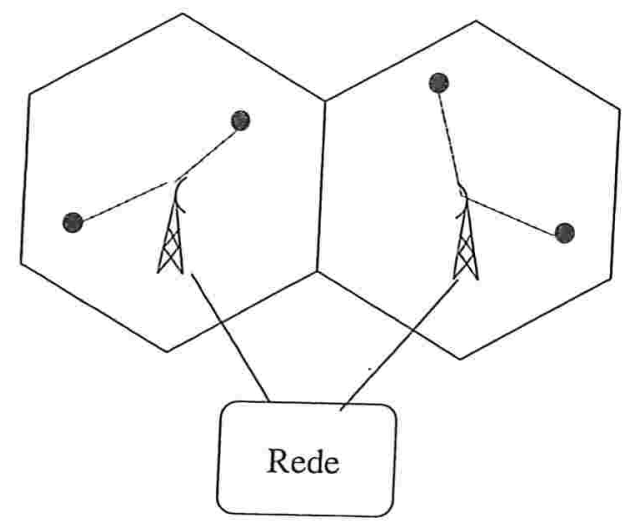

Estação Base de Rádio

- Unidade Móvel

Comunicação sem fio

- Comunicação com fio

Figura 1.1. Ambiente de computação móvel.

inerentes a computação móvel é o conceito de localização das unidades móveis, pois dependendo da posição, atual ou futura, os serviços requisitados por esta unidade podem oferecer diferentes respostas.

- Comunicação sem fio: Outro fator considerável é a instabilidade do canal, que provoca variações na taxa de transmissão durante a comunicação, podendo até ocorrer desconexões inesperadas. A largura de banda disponível, a alta taxa de erros e os riscos à segurança (comparado aos índices da rede fixa), são dificuldades inerentes ao meio sem fio.

- Portabilidade: Devido à possibilidade de movimentação, os dispositivos móveis ficam menores e mais leves, sendo cada vez mais portáteis. Entretanto, isso pode gerar diversas restrições como limitação de energia, de capacidade de armazenamento e de poder de processamento. Logo, todas estas restrições tem que ser superadas considerando que um dos objetivos da computação móvel é oferecer recursos comparáveis aos conseguidos em um ambiente de computação tradicional, mas com mobilidade [14].

Para que os dispositivos móveis possam se comunicar a qualquer momento, e a qualquer lugar, é necessária uma área geográfica totalmente coberta. Isto é, devem existir células em todas regiões. Uma célula é uma área geográfica atendida por um transmissor, ou melhor, por uma Estação Base de Rádio ${ }^{1}$ (ERB) também chamada de Mobility Support Station (Mss). Esta área é definida por todo ponto onde o sinal transmitido pela ERB possa ser recebido dentro dos limites aceitáveis de ruídos e interferência. Entretanto, as células não tem forma definida, idealmente seriam circulares,

\footnotetext{
${ }^{1}$ Em vários artigos usa-se o termo Estação Rádio Base(ERB), apesar de Estação Base de Rádio ser a tradução de Radio Base Station mais conveniente em português
} 
mas na prática são irregulares, dependendo do relevo e topologia da região. Para fins de análise e simulação, na maioria dos casos as células são representadas por hexágonos [19]. Porém na prática, em alguns pontos podemos ter sinais de mais de uma ERB, nesses casos temos uma sobreposição de células.

Durante o planejamento das regiões atendidas pelo sistema de comunicação, a localização das ERBs deve estar espacialmente distribuída de forma a fornecer sinal à toda a área de cobertura pré definida. Nesse ponto, vários fatores podem interferir nesta cobertura, desde características geográficas da região até fatores climáticos. Devido a fatores como potência do sinal de transmissão, distância entre ERBs, sobreposição, dentre outros, a distribuição deve ser bem dimensionada ou mesmo superdimensionada. Atualmente as redes móveis apresentam como tendência, as micro ou pico células [20], as quais possuem algumas centenas de metros de raio, e possuem menor abrangência geográfica e permitem oferecer mais recursos nas áreas de cobertura.

\subsection{Objetivos}

O trabalho de pesquisa aqui exposto, ilustra estratégias que exploram uma melhora na qualidade de serviço em sistemas de comunicações móveis. Porém, este trabalho não visa todos os aspectos de qualidade, mas sim alguns pontos como:

- Maximizar a possibilidade que uma conexão seja mantida do início até o fim desejado pelo usuário, sem interrupções e independente da mobilidade da Unidade Móvel (UM).

- Balancear o número de unidades móveis entre as Estações de Rádio Base (ERB). Cada ERB oferece ao sistema uma quantidade limitada de recursos, que em algum momento podem estar sobrecarregados, enquanto que ERBs adjacentes podem estar com pouco uso. Logo, um balanceamento de UMs entre estas ERBs melhora a distribuição dos recursos disponíveis.

\subsection{Organização do texto}

Esta dissertação está organizada da seguinte forma: o próximo Capítulo "Os Canais", apresenta como os dados são transmitidos, assim como a interferência e formas de planejamento do uso dos canais. Em seguida o Capítulo "Alocação de Canais" relata as técnicas utilizadas para o uso dos canais, assim como sua distribuição e processos derivados deste fato. Já no capítulo seguinte, propomos um modelo que utiliza estratégias de transição de unidades móveis entre células com 
balanceamento de carga, para atender aos objetivos desta dissertação. O Capítulo "A Mobilidade", apresenta a necessidade do uso de modelos de mobilidade, para uma melhor avaliação do comportamento de sistemas de computação móvel. Ainda neste capítulo, veremos o modelo utilizado nos testes e simulações apresentados nesta dissertação. O Capítulo "O Simulador" apresenta o estudo de simuladores para computação móvel, o motivo de optar pela implementação do simulador próprio, assim como a sua construção. O Capítulo "Simulação" apresenta os métodos, configurações e resultados das estratégias sugeridas, comparando-as com a estratégia tradicional. Enfim, para finalizar temos o Capítulo das considerações finais onde estão inseridas as perspectivas e conclusões. 


\title{
Capítulo 2
}

\section{Os Canais}

\begin{abstract}
As comunicações entre as unidades móveis e as ERBs, se dão por ondas eletromagnéticas, $e$ através delas que são formados os canais de comunicação. Os canais são compartilhados pelo sistema para prover acesso à rede fixa, no entanto a forma como os canais são designados às unidades pode ser obtida através de diversas técnicas. Dentre elas a FDMA, TDMA e a CDMA. Além disto, a interferência é um dos fatores limitantes do desempenho do sistema celular, e o planejamento cuidadoso dos canais pode minimizar os seus efeitos.
\end{abstract}

\subsection{Definições}

Os canais são responsáveis por "carregar" as informações que são geradas, ou requisitadas pelas unidades móveis. Os sistemas móveis também sofrem com o limite de espectro de freqüências disponível para canais de rádio. Este problema limita sua banda passante assim como a quantidade de canais. Consequentemente, limita a taxa de transmissão conseguida por usuário, bem como o número total de usuários admitidos no sistema simultaneamente. Nestes sistemas os canais de rádio são os recursos primordiais para estabelecer a conexão dos usuários com a rede fixa. Além disso a utilização eficiente dos canais sempre constituiu um fator importante para a Qualidade de Serviço (QoS) dos sistemas.

Os canais são definidos a partir do espectro de freqüência, sendo este um recurso limitado e que exige um tratamento a fim de compartilhar o meio de comunicação. As técnicas mais utilizadas usam princípios básicos para dividir o espectro, por exemplo, dividir em várias faixas de freqüência, 
com base no tempo (slots de tempo), ou mesmo uma divisão baseada em uma codificação que permita usar todo o espectro disponível, sem que existam problemas de compartilhamento.

O compartilhamento de recursos é uma forma muito eficiente de se obter alta capacidade em uma rede de comunicações. Os canais disponíveis são os recursos que o mecanismo de acesso deve compartilhar para que qualquer terminal acesse o sistema. Uma das formas onde os canais são designados aos usuários por demanda, é o esquema chamado de Acesso Múltiplo com Alocação por Demanda, ou simplesmente Múltiplo Acesso [30].

De acordo com a forma com que o espectro é disponibilizado aos usuários, tem-se a classificação geral de sistemas em Faixa Estreita ou Faixa Larga. Em um sistema faixa estreita, a faixa de freqüências é subdividida em várias faixas menores. Em sistemas faixa larga, toda ou grande parte da banda de freqüências é disponibilizada aos usuários, como um único bloco.

Há pelo menos três formas básicas de se realizar múltiplo acesso, nomeadas de acordo com o mecanismo chave usado para implementá-las:

- Múltiplo Acesso por Divisão de Freqüência (FDMA);

- Múltiplo Acesso por Divisão de Tempo (TDMA);

- Múltiplo Acesso por Divisão de Código (CDMA).

Enquanto o FDMA e o CDMA são, respectivamente, técnicas faixa estreita e faixa larga por natureza, o TDMA permite ambas as formas de implementação [29].

\subsection{Múltiplo acesso}

- FDMA.

A maneira usual de se realizar um esquema FDMA é através da associação de um canal a cada pequena faixa do espectro de freqüência, de forma a minimizar a interferência gerada pela proximidade de faixa de freqüência adjacentes (Figura 2.1). Usualmente, o que se chama de "canal" são as duas bandas associadas ao par de portadoras, direta (base para móvel) e reversa (móvel para base). Sistemas FDMA são usualmente implementados segundo a arquitetura faixa estreita. Tanto sistemas analógicos como digitais podem ser implementados com a técnica FDMA.

- TDMA. 


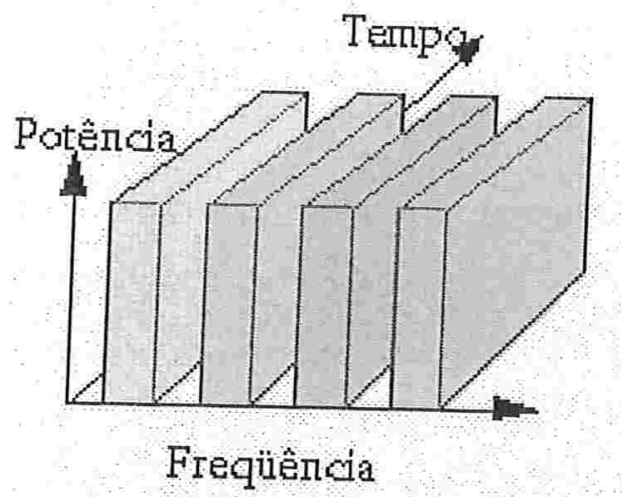

Figura 2.1. Múltiplo Acesso por Divisão de Freqüência (FDMA).

Esta técnica consiste em alocar os canais segundo um espaçamento temporal. Cada faixa de freqüência é dividida em pequenos intervalos de tempo, através de informações contidas em cada intervalo obtem-se os dados a qual dispositivo a informação pertence. Em alguns modelos é feita uma combinação com o processo de divisão de freqüências, desta forma temos uma pequena faixa de freqüência que é dividida em intervalos de tempo (TDMA faixa estreita). A Figura 2.2 mostra um diagrama de transmissão no modelo TDMA. A transmissão ocorre em rajadas, cada usuário transmite ou recebe sua informação numa rajada dentro dos respectivos intervalos. Essa forma de transmissão também leva a um menor desgate de bateria se comparado ao FDMA. Entretanto existe uma sobrecarga de informações de controle (overhead), a característica de transmissão em rajadas requer um tratamento mais minucioso no que diz respeito à sincronização. Os bits necessários nesse tratamento em conjunto com o fato de haver intervalos de tempo, gera um alto custo adicional.

- CDMA.

A técnica CDMA possui as seguintes características básicas: todos os usuários podem transmitir simultaneamente, nas mesmas freqüências e utilizando toda a banda disponível. Ao invés de se fazer a separação entre usuários através de freqüência ou freqüência / tempo, a cada usuário é designado um código, de forma que sua transmissão possa ser identificada. Os códigos usados têm baixa correlação cruzada (idealmente zero), ou seja, são ortogonais, fazendo com que as informações contidas nas várias transmissões não se confundam. No outro extremo da comunicação, o receptor tem conhecimento do código usado, tornando possível a decodificação apenas da informação de seu interlocutor. O CDMA baseia-se em um conceito 


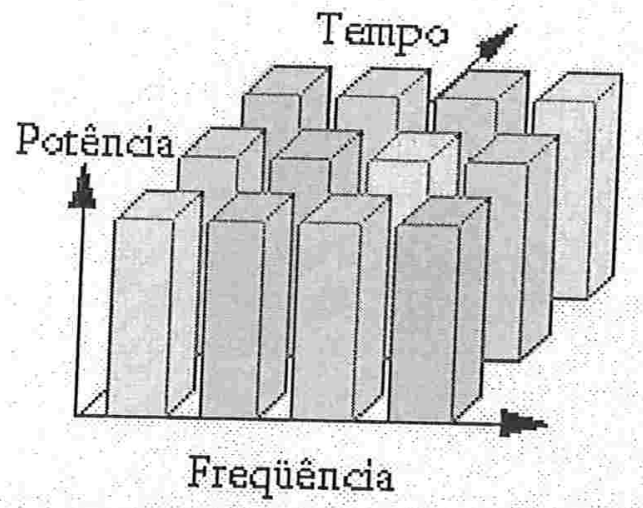

Figura 2.2. Múltiplo Acesso por Divisão de Tempo (TDMA).

denominado espalhamento espectral (Spread Spectrum). Através dessa técnica, o sinal original que se deseja transmitir é espalhado por uma banda muito maior que a necessária para sua transmissão, mesmo assim a energia total é mantida. Uma das técnicas de espalhamento espectral bastante difundida, o salto em freqüência, utiliza um código que determina em qual será a ordem que a freqüência é alterada. Isto é, de tempos em tempos, o sinal portador do sinal altera sua freqüência numa ordem pré estabelecida, que é conhecida apenas pelo transmissor e pelo receptor. Através do código apropriado, a informação do usuário desejado é extraída do meio (Figura 2.3).

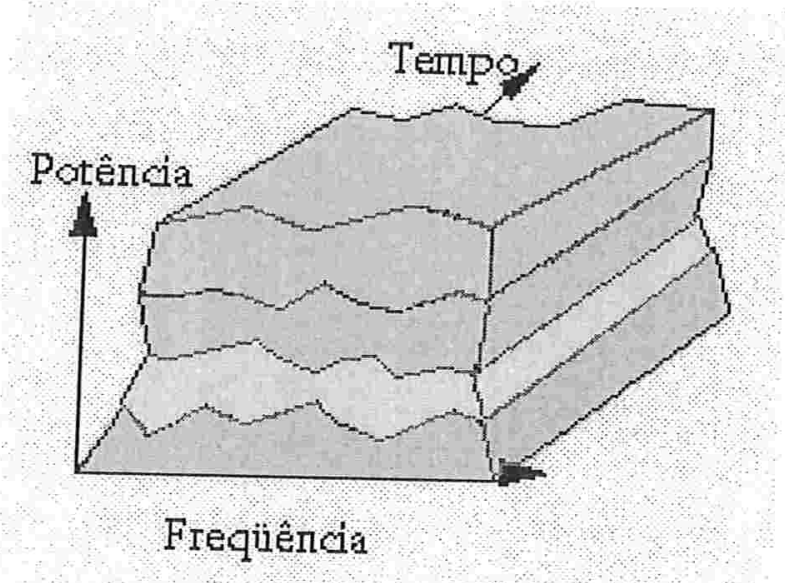

Figura 2.3. Múltiplo Acesso por Divisão de Código (CDMA). 


\subsection{Interferência}

Os canais são gerenciados de forma a atender a demanda dos usuários utilizando-se o princípio da reutilização de freqüências. Com a limitação do número de canais disponíveis, mais do que uma ERB utiliza o mesmo grupo de freqüências para a comunicação com as UMs, entretanto este reuso pode gerar interferências que prejudicam o sistema.

Interferência é o maior fator limitante no desempenho de sistemas celulares. Fontes de interferência incluem: outra unidade móvel na mesma célula, uma chamada em andamento em uma célula vizinha, outras estações base operando na mesma faixa de freqüências, ou algum sistema não-celular que cause interferência ao sistema celular. Os dois principais tipos de interferência gerada no próprio sistema celular são a interferência co-canal e a interferência de canal adjacente.

$O$ reuso de frequências implica que em uma dada área de cobertura existam algumas células que utilizam um mesmo conjunto de freqüências. A utilização destas células em posições geograficamente próximas podem gerar interferência, a qual é denominada interferência co-canal. Para reduzir esta interferência, as células co-canal devem ser espaçadas por uma distância mínima, de forma que seja garantido um isolamento adequado entre elas. O cálculo de interferência é feito através da relação entre o sinal desejado, e os sinais interferentes [29], sendo que a razão entre eles deve ser maior que um limiar conhecido.

Interferências que resultam de sinais que estão numa faixa de freqüências adjacente à faixa do sinal utilizado pela UM são chamadas interferências de canal adjacente. Em alguns casos, a estação base pode ter dificuldade em se comunicar com um usuário cujo sinal está fraco. A interferência de canal adjacente pode ser minimizada através de filtragem adequada e uma correta alocação de canais entre células. Como para cada célula é alocada apenas uma fração dos canais disponíveis, deve ser evitada a alocação, para uma mesma célula, de canais de freqüência adjacentes. A interferência de canal adjacente pode ser reduzida, através do afastamento das faixas de freqüência pelo processo de alocação de canais [29]. Esquemas de alocação de canal devem também prevenir uma outra fonte de interferência de canal adjacente, que é o uso de canais adjacentes em células vizinhas. Esse é um problema de solução ainda mais complexa.

Geralmente, para efeito da alocação dos canais é utilizado como parâmetro a distância mínima de reuso, que corresponde a menor distância física para o uso de dois canais com a mesma freqüência (Figura 2.4). Nesta dissertação, o conceito de canal empregado será independente do método de acesso ao meio. 


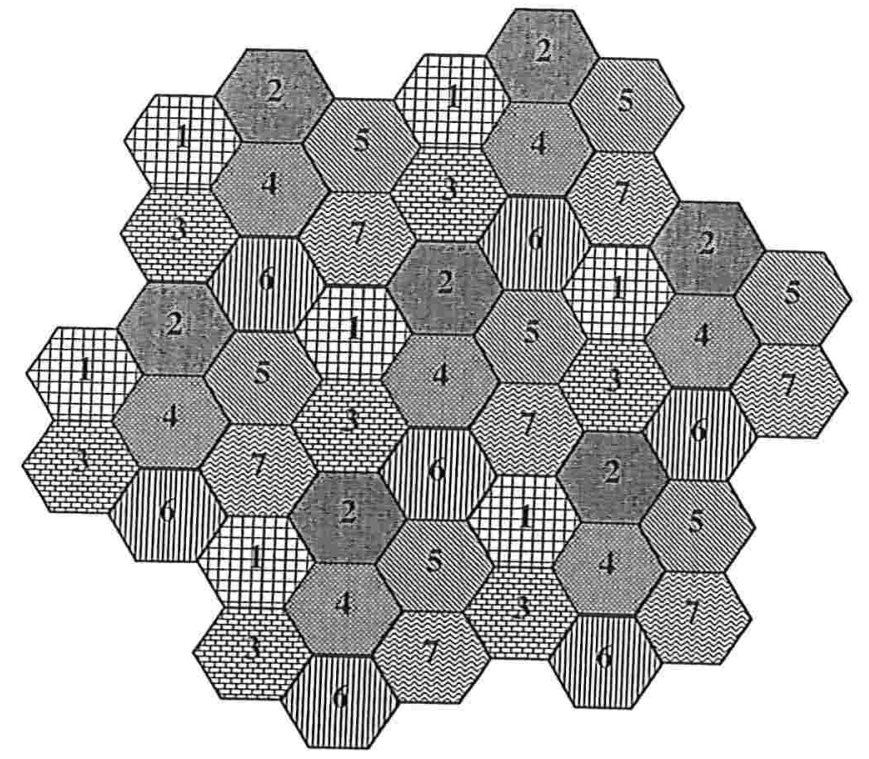

Figura 2.4. Esquema com reuso de canais, com fator igual a 7 (Cada cor ou número corresponde a um conjunto de canais).

\subsection{Planejamento dos canais}

O planejamento de canais, de forma geral, representa o processo de distribuição de canais para cada ERB, o qual deve ser otimizado.

Cada ERB é a responsável por fornecer um, ou mais, de seus canais disponíveis para cada unidade móvel localizada em sua área de cobertura. Com a tendência de diminuição destas áreas para um quadro de micro/pico células [20], existe uma maior possibilidade de uma UM migrar de uma região coberta por uma ERB para outra, consequentemente aumentando a preocupação em manter a conexão durante estas transições.

De uma outra forma pode-se dizer que quando uma nova chamada é efetuada, e esta não obtem um canal para sua conexão, o "tempo real de permanência da chamada" (TRPC) é zero. Quando uma nova chamada consegue um canal e completa a ligação até o fim do serviço, caracteriza-se como "tempo exigido de permanência de chamada" (TEPC) o tempo total desta ligação, que neste caso 
também é igual a TRPC (Figura 2.5). Existe ainda a situação em que uma chamada consegue um canal, mas a unidade movimenta-se e entra na área de atuação de outra ERB, gerando o processo hand-off ${ }^{1}$. Neste processo há uma negociação de um novo canal para esta unidade, e se por ventura não há disponibilidade de um canal, então a ligação é interrompida. Neste caso considerase $0<T R P C<T E P C$ [21]. Como mencionado anteriormente, um dos objetivos desta dissertação é manter o TRPC próximo a TEPC, ou seja, manter a conexão do início até o fim desejado pelo usuário.

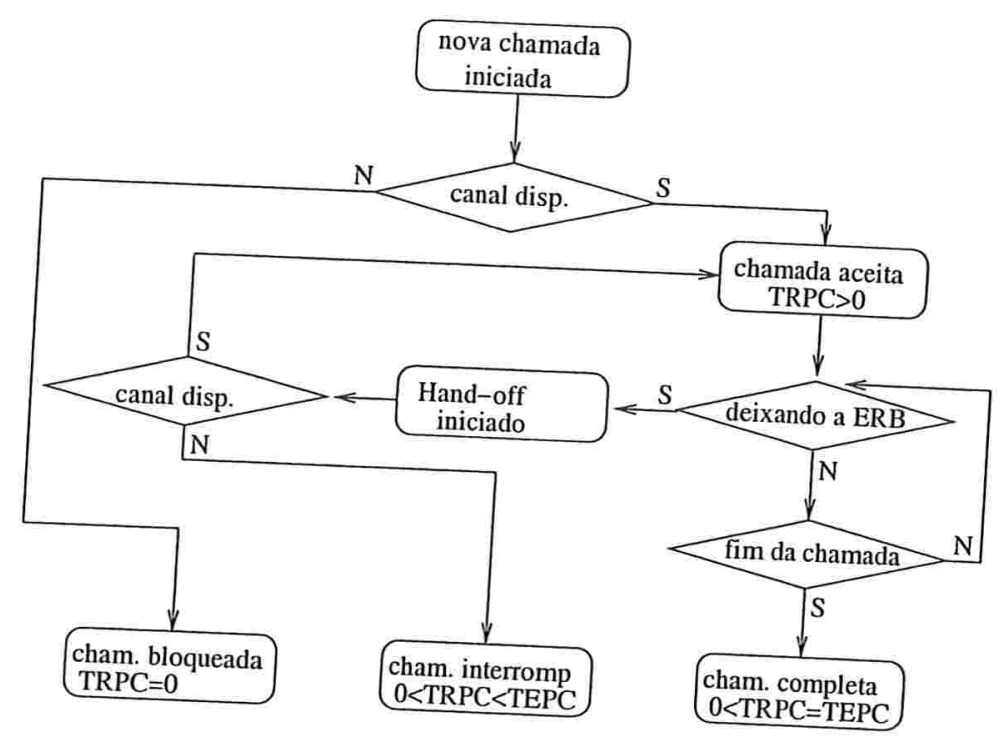

Figura 2.5. Diagrama de comunicação de uma unidade móvel.

Estratégias de alocação de canais devem seguir a linha do paradigma de conexão a "qualquer lugar e a qualquer momento". Nos próximos capítulos relatamos técnicas para alocação de canais, e propomos algumas otimizações.

\footnotetext{
${ }^{1}$ o termo hand-off não foi traduzido, pois manifesta um processo de negociação para a troca de canais de rádio de uma unidade móvel, e não foi encontrada uma palavra em português que transmita o mesmo significado.
} 


\section{Capítulo 3}

\section{Alocação de Canais}

A alocação de canais consiste em distribuir um conjunto de canais disponíveis no sistema entre as Estações Base de Rádio. Este capítulo apresenta formas tradicionais de alocação, dentre elas as alocações Fixa, Dinâmica, e Hibrida. A transição das unidades móveis de uma célula para outra é tratada pelo processo chamado hand-off. Este capítulo ainda trata do enfileiramento das requisições de hand-off, além de casos onde é feita uma reserva de canais exclusivos para o hand-off.

\subsection{Definições}

A alocação de canais consiste em distribuir um conjunto de canais disponíveis no sistema entre as ERBs, sempre observando os pré requisitos existentes. A relação custo/benefício está diretamente relacionada a uma eficiente exploração do espectro de freqüências e a quantidade de ERBs instaladas no ambiente. Nesta dissertação a alocação é vista dentro de um contexto bastante usual que consiste na alocação de canais para o atender às unidades móveis.

Os problemas de alocação de canais são bastante complexos, e em sua grande maioria são problemas de otimização combinatória que exploram modelos e algoritmos já conhecidos [24].

Para exemplificar a complexidade, em [10], o autor caracteriza matematicamente a alocação de canais como um problema de coloração de grafos. Além desta, existe uma proposta para redes genéricas em [18], usando CDMA, que apresenta um algoritmo centralizado para alocação baseado também em coloração de grafos. Outra alternativa são os grafos de interferência [13], onde dois nós 
são interligados por um arco se esses interferem entre si. O melhor aproveitamento espacial dos recursos (tempo, frequência, código, etc) se reduz a achar um conjunto máximo de arcos independentes, ou um clique no grafo. Esses problemas são NP-completos [10, 18, 13], e algumas heurísticas são introduzidas para resolução destes problemas.

Várias técnicas de alocação de canais podem ser encontradas na literatura [19], todas com o objetivo de conseguir um gerenciamento eficiente na distribuição dos recursos. Basicamente, as técnicas de alocação são caracterizadas por dois extremos: Alocação Fixa de Canais (AFC) e Alocação Dinâmica de Canais $(\mathrm{ADC})$. Existe também outra técnica que consiste na combinação das duas anteriores, a Alocação Híbrida de Canais (AHC).

\subsection{Alocação fixa}

Nas estratégias com Alocação Fixa de Canais (AFC) os canais são distribuídos entre as células, de forma que cada uma possua seu grupo exclusivo de canais. Esta distribuição de canais deve seguir o critério da distância mínima de reuso, mencionada no capítulo anterior. Este tipo de alocação depende fortemente de um processo de planejamento de freqüências durante a instalação, e não é capaz de se adaptar dinamicamente às variações de tráfego.

Existem basicamente duas estratégias de distribuição: uniformes, ou não uniformes. Nas estratégias uniformes, o mesmo número de canais é distribuído para todas as ERBs. Nas estratégias não uniformes, cada ERB pode ter um número diferente de canais, dependendo do dimensionamento de demanda da região onde ela se encontra. Em simulações [19], sistemas que possuem uma distribuição não uniforme dos canais reduzem os bloqueios de novas chamadas, assim como os bloqueios de hand-off, se comparados aos resultados encontrados em sistemas com distribuição uniforme.

Mesmo com o pré-dimensionamento, existem estratégias que permitem o empréstimo de canais a ERBs vizinhas (sem descaracterizar a AFC). Este empréstimo só pode ser realizado desde que não interfira na distância mínima de reuso. Na Figura 3.1, é demonstrado um empréstimo de um canal da célula com o grupo 1 de frequências. Entretanto, o empréstimo não é permitido, no caso assinalado pela seta pontilhada. Isto em consequência da proximidade de uma célula com o mesmo grupo de freqüências, caso este, que não acontece na situação assinalada pela outra seta.

Dentro deste grupo podemos mencionar duas categorias: Simples e Híbrida, sendo que a primeira permite que qualquer canal disponível possa ser emprestado, enquanto que a segunda separa em dois grupos de canais, os nominais, os quais não podem emprestados, e o grupo com os canais restantes 


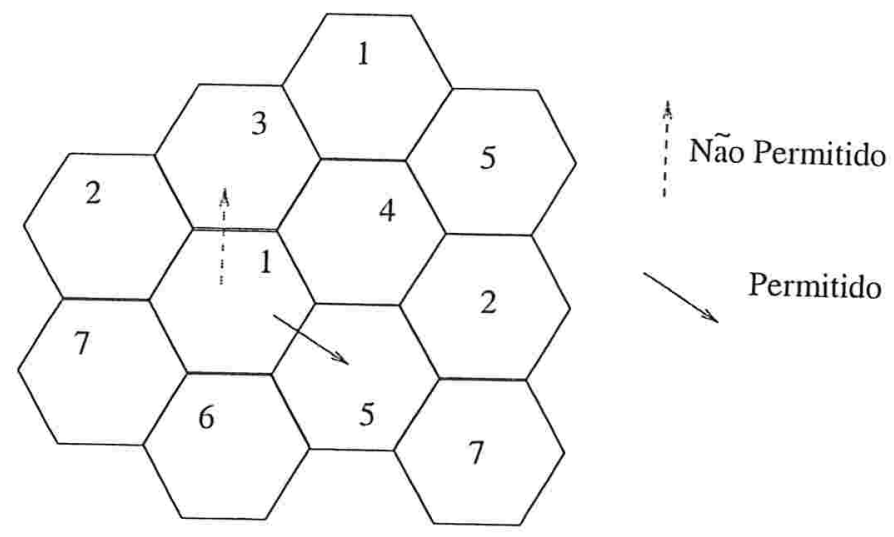

Figura 3.1. Empréstimo de canais.

que podem ser emprestados. Na Tabela 3.1, encontrada em [19], temos uma comparação entre os tipos de alocação fixa de canais.

\begin{tabular}{|c|c|c|l|}
\hline Estratégia & Complexidade & Flexibilidade & $\begin{array}{l}\text { Desempenho de } \\
\text { Alocação }\end{array}$ \\
\hline Fixa (pura) & Baixa & Baixa & $\begin{array}{l}\text { Melhor que ADC e } \\
\text { Empréstimo Híbrido de } \\
\text { canais em alto tráfego }\end{array}$ \\
\hline Empréstimo simples de canais & Moderada-alta & Alta & $\begin{array}{l}\text { Melhor que AFC pura } \\
\text { em tráfego leve ou mo- } \\
\text { derado }\end{array}$ \\
\hline Empréstimo híbrido de canais & Moderado & Moderada & $\begin{array}{l}\text { Melhor que AFC pura } \\
\text { em tráfico leve ou mo- } \\
\text { derado. Melhor que } \\
\text { Empréstimo Simples de } \\
\text { canais com alta carga }\end{array}$ \\
\hline
\end{tabular}

Tabela 3.1. Comparação entre estratégias de alocação fixa de canais.

\subsection{Alocação dinâmica}

Nas técnicas com Alocação Dinâmica de Canais (ADC) não existe uma pré associação dos canais a cada ERB, e os canais são associados dinamicamente conforme a demanda do sistema. Estas 
têm como característica uma melhor adaptação às variações de tráfico do sistema. Entretanto, a escolha de um canal candidato, pode ser uma tarefa complexa. Para demonstrar isto pode-se dizer que a escolha do canal baseia-se em uma função de custo complexa que leva em consideração variáveis como probabilidade de bloqueio em células vizinhas, freqüência de uso de um mesmo canal, distância de reuso, distribuição dos canais por todo sistema, média geral da probabilidade de bloqueio no sistema, dentre outras [19].

Todos os canais podem ser usados por qualquer célula, desde que atendam às condições mínimas de uso para aquela célula. Os algoritmos ADC podem ainda ser classificados como: centralizados ou distribuídos. Nos centralizados, um conjunto de canais é mantido por um controlador central o qual possui informações sobre todos os canais do sistema e os aloca temporariamente conforme a necessidade das ERBs. Nos esquemas distribuídos a decisão de qual canal alocar é tomada por cada uma das ERBs utilizando informações locais sobre os canais disponíveis nas células vizinhas. Ainda podemos destacar dentre os esquemas distribuídos aqueles que tomam como parâmetro básico, o nível de potência do sinal de transmissão. Na Tabela 3.2 é feita a comparação entre as estratégias de alocação dinâmica [19].

Apesar das grandes vantagens aparentes da alocação dinâmica de canais, em situações com muito tráfego, principalmente se o mesmo for uniforme, a alocação fixa de canais tem melhor desempenho [19]. Isto ocorre devido ao fato de que com a ADC, as distâncias entre ERBs com canais de mesmas características, são em média bem maiores que as distâncias mínimas de reuso. Outra consideração está na dificuldade de implementação de soluções ADC, devido a sua complexidade [10].

\begin{tabular}{|l|l|l|l|}
\hline & Centralizados & Distribuídos & $\begin{array}{l}\text { Distribuídos baseados na potência } \\
\text { do sinal }\end{array}$ \\
\hline Vantagens & $\begin{array}{l}\text { Alocação próxima a } \\
\text { ótima }\end{array}$ & $\begin{array}{l}\text { Alocação próxima } \\
\text { a ótima; algoritmos } \\
\text { mais simples }\end{array}$ & $\begin{array}{l}\text { alocação sub-ótima; algoritmo } \\
\text { simples; mínima comunicação com } \\
\text { outras ERBs; processamento em } \\
\text { tempo real; }\end{array}$ \\
\hline Desvantagens & alto fluxo de controle \\
& centralizado & $\begin{array}{l}\text { Grande comunicação } \\
\text { com outras ERB's }\end{array}$ & $\begin{array}{l}\text { Aumento de interferência co- } \\
\text { canal; aumento de interrupção, e } \\
\text { instabilidade }\end{array}$ \\
\hline
\end{tabular}

Tabela 3.2. Comparação entre Estratégias de alocação dinâmica de canais. 


\subsection{Alocação híbrida}

$\mathrm{Na}$ alocação híbrida as estratégias de alocação fixa e dinâmica são combinadas para se obter um bom desempenho em diversas situações de tráfego, uniforme ou não. Neste caso o número de canais disponíveis são divididos entre conjuntos fixos e dinâmicos, sendo eles trabalhados de forma análoga aos esquemas anteriores.

\subsection{Hand-off}

Um grande número de requisições de hand-offs, pode exigir uma maior eficiência da alocação de canais. Para exemplificar isto, em ambiente de micro/pico células a probabilidade de ocorrem hand-offs é maior que em ambientes de células maiores. Gerando uma sobrecarga no sistema, no sentido que sempre que ocorre este processo, existe uma nova disponibilização de canais para atender a unidade móvel que está chegando a esta região. Caso não existam canais disponíveis, ocorre a desconexão da unidade provocando então perda de qualidade no serviço.

Os hand-offs ocorrem de duas formas: forma suave ou "abrupta", o hand-off suave, realiza-se de uma maneira em que a unidade móvel não fica totalmente desconectada. Ela fica conectada através de um enlace de rádio na antiga ERB, e através de outro enlace na outra ERB (para a qual está migrando). Após o registro na nova ERB, ele desfaz o enlace com a antiga ERB. Na forma "abrupta", a unidade móvel se desconecta totalmente da ERB onde está atuando, e revindica um canal para a nova ERB, e só depois do registro ela se reconecta novamente ao sistema, neste caso a unidade móvel passa um pequeno período totalmente desconectada do sistema.

Ainda existem sistemas que estabelecem esquemas que priorizam os hand-offs em relação às novas chamadas com o intuito de manter a qualidade do serviço. Para isto, existem técnicas de Reserva de Canais, e Fila de Requisição de hand-offs.

\subsection{Reserva de canais}

Esta técnica oferece uma maior eficiência para realização de hand-offs. A idéia é simplesmente reservar um número de canais para serem usados somente para o processo de hand-off, sendo que o restante dos canais são compartilhados pelas novas conexões, e pelos hand-offs. Entretanto, deve-se analisar as condições do tráfego do sistema, para avaliar o número correto de canais a serem reservados. Uma desvantagem está na redução do número de canais disponíveis para novas 
conexões, portanto mesmo que existam canais livres, se estes estiverem reservados, estes não poderão ser utilizados.

Em [8], uma estratégia de reserva de canais adaptativa às variações do tráfego é proposta através da avaliação da potência do sinal da unidade móvel. Quando se sabe quando uma unidade móvel se aproxima de uma nova ERB, então é solicitada uma reserva de canal para a nova ERB, é desta forma que as reservas são efetivadas. Assim a capacidade de reserva de canais pode ser eficientemente controlada de acordo com a variação do tráfego.

\subsection{Fila de requisição de hand-offs}

As requisições de hand-offs são colocadas numa fila (FIFO), e atendidas conforme a disponibilidade de canais na célula. Cada requisição permanece nesta fila durante um certo tempo limite, caso ela não seja atendida, então a requisão é cancelada. Este certo tempo limite é definido pelos níveis de potência de sinal das unidades móveis, sendo estabelecidos dois níveis de referência: o limite de recebimento e o limite mínimo. O primeiro consideramos ser o nível onde a potência do sinal de uma nova ERB ultrapassa a potência da ERB atual, e a segunda o nível mínimo aceitável para que exista comunicação. Esta técnica também apresenta melhoras na taxa de bloqueio de hand-offs [19]. 


\title{
Capítulo 4
}

\section{Trabalhos Relacionados à Intersecção de Células}

\begin{abstract}
Muito trabalhos relacionados com a alocação de canais, não retratam especificamente a interseç̧ão entre células. Entretanto, no contexto desta dissertação, esta questão é fundamental. Neste capítulo foram selecionados dois trabalhos que utilizam a interseç̧ão de células como fator fundamental, além de apresentar várias estratégias utilizadas para formar as idéias desta dissertação.
\end{abstract}

\subsection{Considerações iniciais}

Este capítulo apresenta resumos de alguns trabalhos relacionados com esta dissertação. No entanto existe uma variedade de trabalhos que se enquadrariam no mesmo segmento deste trabalho, a alocação de canais. Dentre eles, vários algoritmos de alocação fixa de canais, com características interessantes de empréstimo de canais [38]; ou mesmo trabalhos de alocação dinâmica de canais que utilizam técnicas de Inteligência Artificial [1]. Entretanto vamos focar nos trabalhos relacionados diretamente a característica de sobreposição de células, onde existem regiões que possuem mais do que uma opção de ERB para a conexão.

Entre os esquemas baseados em alocação fixa de canais existem muitas alternativas possíveis para aproveitar a sobreposição de células. Dentre elas, vamos destacar o Direct Retry (DR) e Directed Hand-off $(D H)$, que levam vantagem do fato que alguma porcentagem das unidades móveis poderem 
obter sinal com qualidade de duas ou mais ERBs [19]. Com direct retry, se uma UM realiza uma tentativa de conexão, e a ERB não tiver nenhum canal livre, a UM pode então tentar se conectar a um canal livre em outra ERB, desde que esta possa fornecer um nível suficiente do sinal. Já o esquema do directed hand-off utiliza uma idéia que vai mais além, quando uma ERB tem todos, ou quase todos seus canais em uso, ela pode dirigir algumas das conexões em andamento, em seu domínio, para a ERB adjacente. A motivação está no fato de se poder redistribuir as chamadas das ERBs sobrecarregadas para ERBs com menor carga. Ambos os esquemas acima tem como objetivo melhorar o desempenho do sistema. Os índices de melhoria estão ligados a porcentagem de unidades localizadas nas regiões de sobreposição de células. A seguir dois trabalhos serão abordados, sendo o primeiro um esquema baseado no direct hand-off, e o segundo um esquema que prioriza os hand-offs.

\subsection{Handover seletivo para distribuição de tráfego em comunicações móveis}

Este trabalho, (SHOT) [15], é baseado no conceito de alocação fixa de canais. Nele é proposto uma otimização baseada na sobreposição das células. Se o tráfego de uma célula aumentar temporariamente, de forma que a taxa da utilização do recurso excede um limite predefinido, o SHOT entrega algumas conexões desta célula para outras células adjacentes. Entretanto, apenas as conexões que estiverem em áreas de intersecção de células podem ser redirecionadas através de um hand-off.

Um exemplo da proposta utilizando o SHOT, é mostrado na Figura 4.1. Onde, os índices de Z1 à Z7 representam as células adjacentes. Supondo ainda que todos os canais de Z1 estão ocupados, mas Z2 e Z5 possuam canais livres. Quando uma nova chamada é realizada em Z1, os níveis do sinal de recepção de cada unidade já conectada em Z1 é medida pelas ERBs de Z2 e Z5, neste conjunto um par (ERB e unidade móvel) é escolhido a partir daqueles que obtiverem o melhor nível de sinal. Neste exemplo, a ERB em Z5 pode ser escolhida, desta forma uma unidade em Z1 realizará um hand-off para Z5, deixando agora um canal livre em Z1 para esta nova chamada.

Em [15], quanto maior for a intersecção entre as células, maior será o desempenho do sistema. Os autores propõem sistemas com maiores áreas de interseç̧ão, porém este aumento pode causar excesso de interferência co-canal. A expansão da área de cobertura da células pode deixar o critério da distância mínima de reuso de canais comprometido.

Um melhor desempenho do algoritmo depende de como é selecionada a unidade móvel de uma célula sobrecarregada. O SHOT apresenta três formas de se realizar esta escolha.

Na primeira forma (SHOT1), o algoritmo seleciona a unidade móvel com o nível mínimo da 


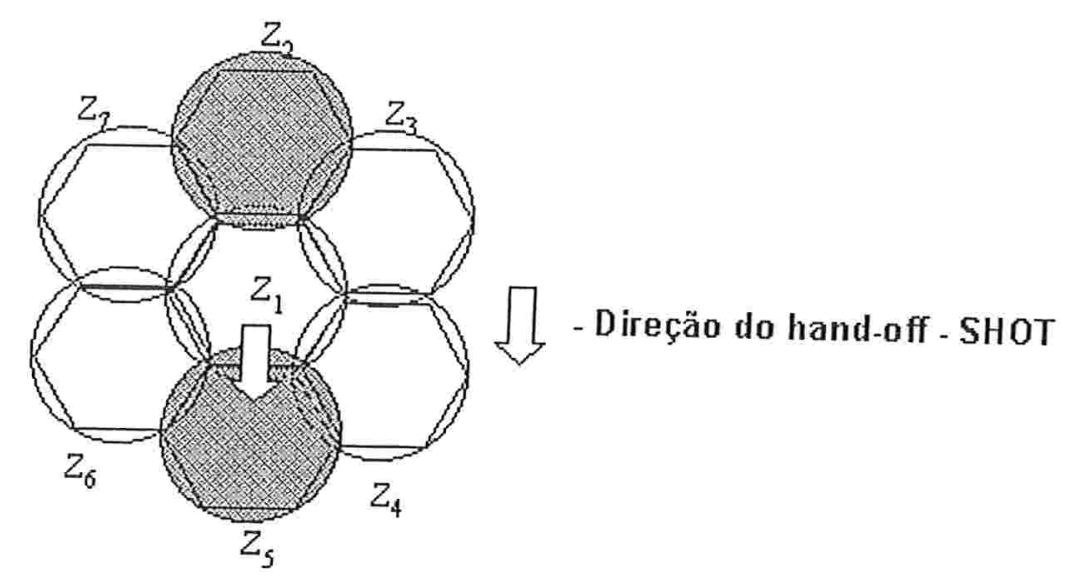

Figura 4.1. Princípio de funcionamento do esquema de Handover seletivo.

recepção. Isto é, a unidade móvel escolhida é aquela mais afastada da estação. Neste caso, só é necessário medir o nível de sinal na ERB atual onde a unidade está conectada. Embora este controle de seleção seja muito simples, a unidade móvel selecionada pode não ter o nível requerido de recepção na nova célula.

Em SHOT2, todas as unidades móveis da ERB em questão medem o nível da recepção das ERBs adjacentes que têm um ou mais canais livres. SHOT2 seleciona a unidade móvel que possui o maior nível de recepção em uma das ERBs adjacentes. Embora o controle em SHOT2 seja mais complexo, este fornece uma melhor qualidade do sinal. Entretanto, SHOT1 e SHOT2 não levam em consideração a interferência co-canal.

Em SHOT3, todas as unidades móveis na ERB atual medem o nível da recepção das ERBs adjacentes que têm ao menos um canal livre. A unidade móvel e a estação que tem o nível mais elevado de recepção são selecionadas. Este será chamado de par de primeira prioridade. De forma análoga, o segundo e terceiro pares serão formados. Cada estação selecionada faz sua unidade móvel medir a possível interferência do canal. O mesmo é aplicado para o segundo e terceiro par. Então o par com menos interferência é selecionado.

Nas simulações realizadas em [15], embora SHOT3 seja um pouco mais complexo, ele fornece uma melhoria no desempenho, porém isto está diretamente relacionado ao nível de interferência co-canal admitido pelo sistema. Dependendo deste nível a melhora pode chegar a $50 \%$ em tráfego uniforme; para condições não uniforme do tráfego, espera-se o mesmo comportamento. Na tabela 4.1, encontra-se uma comparação entre os três algoritmos propostos. 


\begin{tabular}{|l|l|l|}
\hline Esquema & Vantagens & Desvantagens \\
\hline SHOT 1 & Simples controle de seleção & $\begin{array}{l}\text { Não leva em consideração a } \\
\text { interferência co-canal }\end{array}$ \\
\hline SHOT 2 & Moderado controle de seleção & $\begin{array}{l}\text { Não leva em consideração a } \\
\text { interferência co-canal }\end{array}$ \\
\hline SHOT 3 & Maior capacidade de controle do tráfego & Complexo controle de seleção \\
\hline
\end{tabular}

Tabela 4.1. Comparação dos algoritmos propostos em [15].

\subsection{Esquema de reserva de canais adaptativo}

Chang e Sun [8] apresentaram um novo modelo que estabelece um método para reserva de canais para hand-off de forma dinâmica. Este método tem como objetivo garantir a qualidade de serviço (QoS) nas tentativas de hand-off, em sistemas celulares DS-CDMA. Para isso, alguma capacidade do reserva de canais é necessária. Entretanto, uma quantidade fixa de reservas de canais pode provocar perda de eficiência pois requisições de hand-off são feitas de forma variável com o tempo. Este método se adapta às variações da taxa de requisições de hand-off.

Se uma UM encontrar uma ERB vizinha com um sinal mais elevado do que um valor inicial pre-determinado $\left(T_{\text {add }}\right)$, uma nova ligação é estabelecida com a ERB vizinha enquanto a ligação existente é mantida. Neste caso, a chamada é dita estar em hand-off suave, sendo este tipo de handoff utilizado pelos sistemas DS-CDMA. Se o sinal da ERB antiga, ou da ERB nova, cair abaixo de um valor pré-determinado ( $T_{\text {Drop }}$ ), a ligação correspondente é liberada [36]. A Figura 4.2 ilustra a variação típica do sinal enquanto uma UM sai da área de uma ERB.

É proposto um novo parâmetro $\left(T_{R s v r}\right)$, que é o ponto inicial de pedidos de reserva de canais. Este valor é menor do que $T_{a d d}$. Se uma UM encontrar qualquer ERB vizinha com o sinal superior a $T_{R s v r}$, a UM emite uma mensagem de pedido de reserva de canais para a ERB vizinha. Mais tarde, se a potência do sinal cair e permanecer abaixo de $T_{R s v r}$ durante um período predeterminado, a UM pede à ERB associada para liberar a reserva do canal. Por outro lado, se a potência do sinal alcançar $T_{\text {add }}$, então a UM inicia o hand-off usando o canal reservado. Entretanto, a quantidade de reservas de canais é limitada por um valor máximo pré-determinado. O $T_{R s v r}$ não é um valor absoluto, é um valor proporcional a $T_{\text {add }}$.

A capacidade do sistema depende também da diferença de QoS entre o bloqueio de novas chamadas e as falhas de hand-off [32]. Se for dada maior prioridade para as novas chamadas, isto causa 


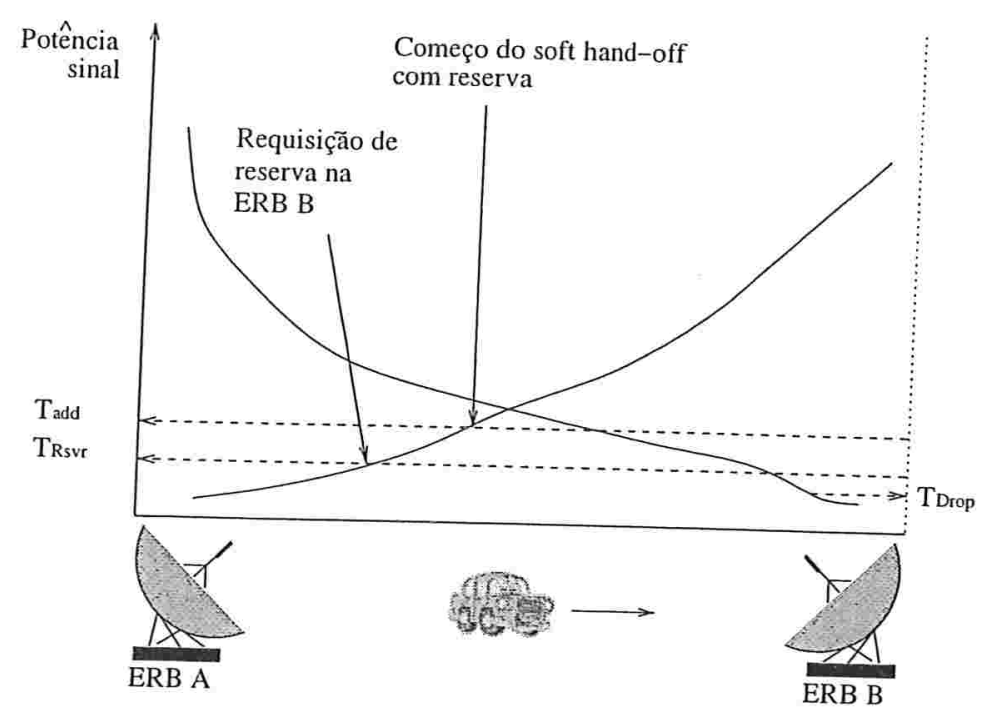

Figura 4.2. Reserva de canais para hand-off por mecanismo de limite de sinal.

um aumento nas falhas de hand-off, e vice-versa. Assim, a capacidade do sistema é máxima quando a probabilidade de bloqueio de novas chamadas é igual à probabilidade de falha de hand-off.

Para manter um equilíbrio entre as probabilidades, o esquema proposto controla o tamanho da capacidade mínima de reservas, contando os números de bloqueios de novas chamadas e as falhas de hand-off. Isto é feito através de um mecanismo de sensoriamento proposto em [8].

Surge um problema muito difícil, que é a escolha do intervalo apropriado de tempo que monitore o sistema, pois o tráfego oferecido varia com o tempo. Um intervalo curto pode ser insuficiente para oferecer uma estimativa, de forma a determinar o tamanho da capacidade de reserva [27]. Por outro lado, a variação dinâmica do tráfego faz o processo de reserva ineficiente, no caso em que o intervalo de monitoração for demasiadamente longo. Então, o mecanismo proposto atualiza o valor gradualmente de acordo com a variação dinâmica do tráfego.

Em [8], além de incluir procedimentos de equilíbrio entre a probabilidade de bloqueio de novas conexões e bloqueio de hand-offs. Seu desempenho é analisado por um modelo Markoviano em simulações. Este apresenta melhoras em relação aos modelos de reserva fixa de canais. Segundo os autores este esquema pode ser usado em várias situações práticas com robustez.

\subsection{Análise dos trabalhos}

Nesta dissertação, parte das idéias apresentadas em SHOT são utilizadas. Ao realizar uma análise crítica, o SHOT baseia-se no nível de sinal de transmissão/recepção. No entanto estes sinais são 
instáveis podendo ter variações pela distância, mudanças temporais, ou mesmo pela localidade da unidade móvel. Por exemplo, em um local fechado existe uma sensível redução do sinal proveniente de uma ERB, o que pode causar problemas na eficiência dos algoritmos propostos por [15]. Além disso, aumentar a área de cobertura das estações implica em um aumento de potência das antenas, gerando maior consumo de energia tanto por parte das estações como das unidades móveis, gerando assim outros problemas relacionados ao consumo de energia. Com relação ao modelo adaptativo de reserva de canais, o mesmo apresenta resultados que demonstram que a priorizar o hand-off ajudam a garantir a QoS do sistema.

As estratégias elaboradas no modelo sugerido desta dissertação utilizam as idéias baseadas em [15], porém não baseam-se nos níveis de sinais e sim nas regiões de intersecção de células. Além disso, definem estratégias que priorizam o hand-off, a fim de garantir a QoS do sistema. 


\title{
Capítulo 5
}

\section{Modelo Sugerido}

\begin{abstract}
Neste capítulo apresentamos a motivação e o detalhamento de um modelo que considera a intersecção de áreas de cobertura das ERBs adjacentes. Três estratégias são apresentadas para melhora do sistema, assim como as formas de balanceamento da carga, categorizadas como balanceamento de carga crítica e permanente.
\end{abstract}

\subsection{Considerações iniciais}

Em grande parte dos trabalhos da literatura, as áreas de cobertura das ERBs são consideradas disjuntas. Quando uma UM se dirige de uma área a outra, e atravessa a fronteira é necessário efetuar o hand-off. Entretanto, pode ser que o sinal da ERB inicial ainda seja de boa qualidade. Podemos ver na Figura 5.1, o funcionamento do modelo tradicional. No caso da UM em movimento, representada à esquerda, quanto mais próxima de uma ERB, melhor será a qualidade de sinal. A área de cobertura de cada ERB é representada por um hexágono, e a fronteira entre as ERBs é representada por uma linha. Isto é, a intersecção de regiões com sinal aceitável é considerada nula. Em termos práticos a fronteira entre ERBs pode ser definida observando-se a potência do sinal recebido. Esta região de hand-off está representada na Figura 5.1 pelo retângulo cinza.

A área de cobertura de uma ERB é determinada pelo espaço em que a potência do seu sinal é maior do que a potência de sinal das outras ERBs. Do ponto de vista da UM, nos modelos tradicionais o hand-off deve ser feito quando a potência de sinal de uma outra ERB for maior, considerando uma tolerância pré-determinada. Pode-se usar esta tolerância para evitar que ocorram vários hand-offs desnecessários quando uma UM se movimenta próxima a fronteira de duas ERBs. 

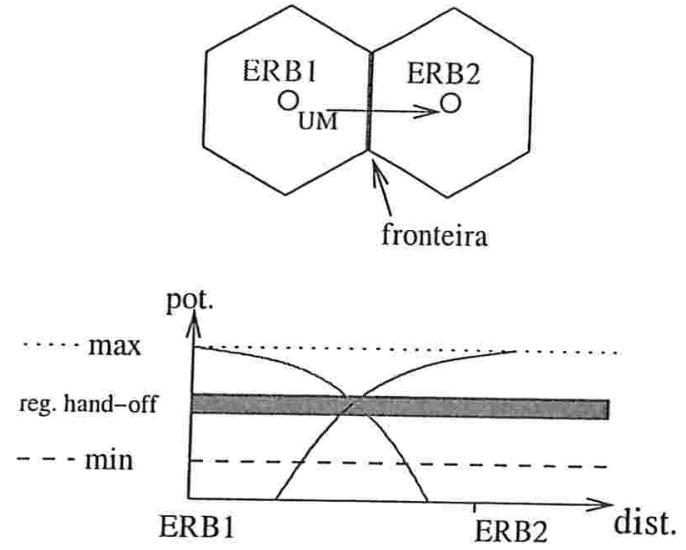

Figura 5.1. Diagrama de nível de sinal no modelo tradicional

Observando que o sinal de uma $\mathrm{ERB}$, digamos $\mathrm{ERB}_{1}$, continua satisfatório até o ponto de nível mínimo de sinal. Podemos definir uma outra política de hand-off, onde uma UM efetua o hand-off apenas quando o sinal do canal utilizado chega ao nível mínimo necessário para a comunicação. Entretanto, para garantir que nenhuma UM fique com um sinal muito próximo do nível mínimo, definimos um limite para hand-off, onde mesmo se o sinal continuar satisfatório, o hand-off para uma outra base mais forte deve ser iniciado.

Nesta segunda política, o número de hand-offs de uma UM, durante a sua movimentação, pode ser reduzido. Isto pode ser visto na Figura 5.2, onde uma UM faz um movimento "tangente" à região de fronteira da $\mathrm{ERB}_{2}$. A UM teria que efetuar três trocas de base com a política tradicional, e nenhuma com a esta segunda política.

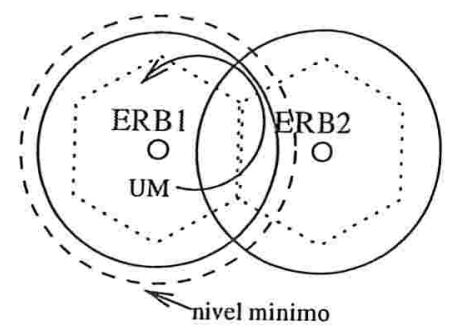

Figura 5.2. UM com trajetória tangente a $\mathrm{ERB}_{2}$.

Para as duas políticas apresentadas o hand-off depende apenas da mobilidade da UM e é esta que decide se muda de base. Entretanto, conforme podemos ver na Figura 5.3, existem regiões de hand-off, onde a UM tem mais de um sinal disponível.

A idéia básica do modelo, consiste em aproveitar a existência de regiões geográficas que podem 


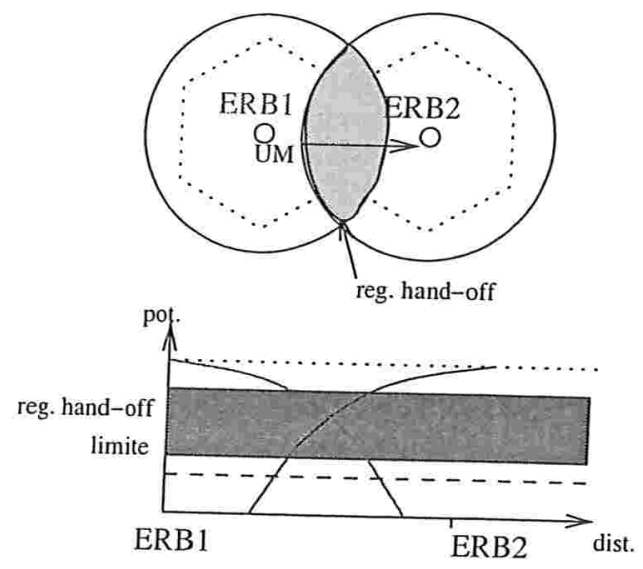

Figura 5.3. Diagrama de nível de sinal no modelo com intersecção.

ser atendidas por mais de uma ERB (uma idéia semelhante foi utilizada em $[8,15]$ ). A decisão de transferir uma UM, em uma região de intersecção, fica a cargo da ERB que estiver responsável por esta UM. Além disto, em situações reais, uma porcentagem razoável, de 30 a $45 \%$ das UMs está em áreas de intersecção [12]. Cabe então ao modelo estipular uma estratégia para repartir as UMs em áreas de intersecção.

\subsection{Grafo de adjacências}

Para armazenar de forma eficiente em cada ERB suas regiões de intersecção, utilizaremos um grafo de adjacência. Assim, a partir de informações dos níveis de potência de sinal que cada UM está recebendo, pode-se deduzir facilmente a região de sua localização (desde que estas informações sejam repassadas à ERB). Usamos, um grafo bipartido cujos nós representam tanto as regiões de intersecção geográficas (nós negros) como as ERBs (nós brancos). As arestas representam a possibilidade de conexão com a ERB na região em questão (Figura 5.5). Por exemplo, na célula $I$ temos a região 1 que é atendida por apenas por uma ERB. As regiões 2 a 7 são atendidas por mais de uma ERB (Figura 5.4).

Cada UM ativa estará associada a uma única aresta, que por sua vez está ligada a um nó negro (região) e um nó branco (ERB). Para que isto seja possível, consideramos que uma UM informa a sua ERB responsável o nó negro a qual está associado, o qual é obtido através da recepção dos sinais das ERBs adjacentes (estratégia também utilizada em [20]). A Tabela 5.1 contêm apenas os sinais dentro dos valores limites de tolerância de qualidade, e também mostra um exemplo com dados. Exemplificando, é através destes dados que a ERB responsável pela UM pode deduzir a qual 


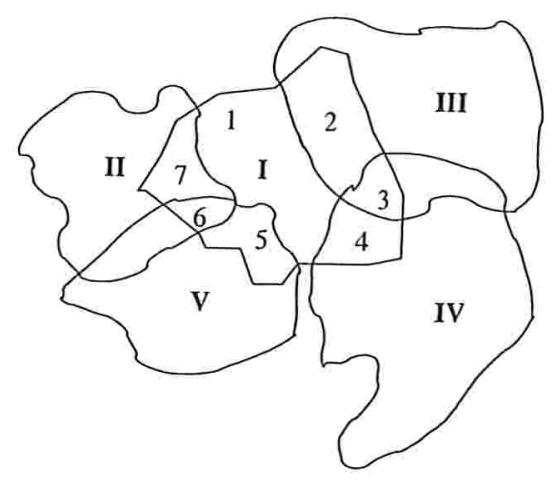

Figura 5.4. Distribuição da área de abrangência de ERBs adjacentes.

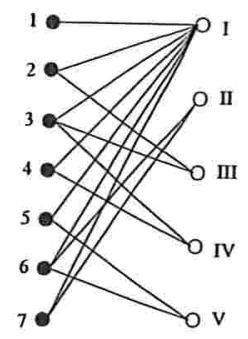

Figura 5.5. Representação das relações de adjacência entre regiões e ERBs por um grafo bipartido.

nó negro a UM pertence, consequentemente consegue-se identificar dentro do grafo, qual é a aresta da UM. É interessante notar que a UM só informa a ERB enquanto estiver conectada e se existir uma mudança de nó negro.

\begin{tabular}{|c|c|}
\hline ERB & Potência do sinal \\
\hline I & $90 \mathrm{db}$ \\
\hline II & $70 \mathrm{db}$ \\
\hline V & $80 \mathrm{db}$ \\
\hline
\end{tabular}

Tabela 5.1. Níveis de sinal.

A respeito da criação deste grafo, podemos abordá-la de duas formas:

- Fixa - Durante a instalação e configuração da ERB, pode-se registrar todas as ERBs adjacentes, assim como as possíveis áreas de intersecção entre as células;

- Dinâmica - Como as UMs durante a conexão informam quais são as ERBs das quais elas 
recebem sinal para conexão [20], é possível que um processo na ERB receba estas informações e conseqüentemente crie o grafo.

A Tabela 5.2 ilustra as vantagens e desvantagens das formas de criação do grafo de adjacências. Considerando as vantagens da forma fixa, esta foi empregada na simulação.

\begin{tabular}{|l|c|l|}
\hline Forma & \multicolumn{1}{|c|}{ Vantagens } & Desvantagens \\
\hline Fixa & Implementação simples & $\begin{array}{l}\text { A instalação de uma ERB } \\
\text { implica em uma nova confi- } \\
\text { guração manual do grafo }\end{array}$ \\
\hline Dinâmica & Possui configuração automática do grafo & $\begin{array}{l}\text { Necessita de processo de mo- } \\
\text { nitoramento na ERB }\end{array}$ \\
\hline
\end{tabular}

Tabela 5.2. Comparação das formas de criação do grafo de adjacência.

$\mathrm{Na}$ verdade o tamanho e forma das regiões das células variam segundo vários fatores como: horário do dia, condições metereológicas, dentre outros. No entanto, esta variação não implica em incompatibilidade no grafo de adjacência, considerando que o grafo tem todas as interseções possíveis entre células. Por exemplo, na Figura 5.4 em uma situação onde as regiões atendidas pela ERB $I I$ e $V$ diminuem de tamanho por algum fator, isto pode provocar o desaparecimento da região de intersecção número 6. Assim o nó negro referente a região 6 fica inativo. Esta situação, como outras provenientes da alteração do tamanho e forma das células, não implicam em problemas para a aplicação do modelo.

Todo processamento relativo à transferência de UMs será realizado de forma distribuída nas ERBs. Uma UM pode mudar de ERB em dois casos: Primeiro, em caso de mobilidade da UM, quando o sinal da ERB a qual a UM está conectada é inferior ao de outra ERB. Segundo, em caso de balanceamento de carga sob ordem de uma ERB. Este caso ocorre quando uma ERB está utilizando mais canais que ERBs adjacentes, e existem UMs em áreas de intersecção com ERBs adjacentes menos carregadas. No primeiro caso, o sistema móvel não tem outra alternativa, a não ser aceitar a solicitação. Já no segundo caso serão consideradas algumas características do ambiente móvel, para decidir se há necessidade de "forçar" um hand-off de uma tal UM, e para qual nova ERB ela deverá ser associada.

Outro tipo de informação que será levado em consideração será o estado atual da capacidade de uso de cada ERB, sendo esta a grande variante na decisão de haver ou não um hand-off "imposto". 
Esta informação pode ser tanto relativa quanto absoluta. Com relação à alocação de novos canais, as opções de ERBs a qual uma UM possa associar-se, dependerá da região onde ela se encontra, isto é, se na região onde se encontra existirem uma, ou mais, ERBs atuando.

\subsection{Balanceamento de carga}

No modelo apresentado, existem áreas de intersecção, onde os sinais de mais de uma ERB estão disponíveis para a comunicação com as UMs. Nesta seção apresentaremos estratégias para a escolha de ERB que atenderá as UMs nestas áreas.

Nas estratégias propostas, todo o processamento relativo ao balanceamento de carga será feito nas ERBs, de forma distribuída. Esta escolha foi motivada por duas razões: de um lado não se pode garantir que a UM terá capacidade de processamento, nem que a UM permanecerá conectada durante todo o procedimento de balanceamento. Por outro lado, mesmo que a comunicação entre as ERBs através de uma rede fixa seja muito rápida, a concentração de todo o balanceamento em um único servidor pode limitar as possibilidades de uso prático do modelo. Além disso, o comportamento das estratégias devem considerar alguns fatores:

- As estratégias devem atuar no contexto de tempo real, portanto devem ser simples, no intuito de serem processadas rapidamente;

- As estratégias devem ser independentes do esquema de alocação de canais empregado, mas é claro que pode ser necessária uma adaptação das estratégias para maior desempenho do sistema;

- As estratégias, idealmente, deveriam evitar basear-se no nível do sinal obtido pela UMs, devido a instabilidade comum deste sinal. Ou mesmo que esta instabilidade não prejudique o uso das estratégias.

Com estes fatores, e a proposta de transferência de UMs para ERBs adjacentes para balancear o sistema, algumas hipóteses foram levantadas com o objetivo de conseguir encontrar um modelo para as estratégias. São elas:

1. A UM que estiver a mais tempo parada (ou a mais tempo conectada a uma mesma ERB) terá prioridade na transferência para outra ERB adjacente, com o intuito de realizar uma melhor escolha. 
Esta hipótese foi levantada por exclusão, já que uma UM em movimentação possui maiores chances de sair do domínio da ERB. Como não estamos nos baseando no nível do sinal, conforme fatores apresentados anteriormente, temos dificuldades em saber a direção da UM. Assim a UM pode ter acabado de chegar na ERB, ou estar saindo de uma área de intersecção, ou mesmo saindo do domínio da ERB, casos que poderiam prejudicar o desempenho do modelo, visto que a UM poderia estar sendo transferida para outra ERB, que não seja a ERB que em breve a UM estaria se tranferindo naturalmente.

2. Direcionar uma UM sempre para uma ERB adjacente com a menor carga, desta forma alcançando melhores resultados de balanceamento.

Podem existir ERBs com uma quantidade de unidades maior que suas ERBs adjacentes, assim é conveniente repartir estas unidades a mais, com as ERBs menos sobrecarregadas. Entretanto, com base nesta hipótese, pode haver uma distribuição concentrada em uma ERB com a menor carga. Assim nos leva a possibilidade da próxima hipótese.

3. Realizar um rodízio entre as ERBs adjacentes com carga abaixo da ERB em questão, com o objetivos de minimizar a concentração da distribuição de UMs em uma única ERB adjacente.

Na próxima subseção as estratégias de balanceamento de carga são apresentadas, as quais consideram os fatores e hipóteses levantadas. Além disso, todas as hipóteses levantadas são esclarecidas na análise dos resultados da simulação.

\subsubsection{Carga crítica}

Neste caso definimos, para cada ERB, um limite de carga crítica. A definição de carga se dará através de percentuais relativos à capacidade de canais ocupados de cada ERB. Os valores adequados deverão ser determinados através de simulações. Caso uma ERB atinja a carga crítica esta deve consultar para cada ERB adjacente o seu estado de carga. Caso exista uma UM em uma área de intersecção com uma ERB abaixo do limite, a UM deve ser transferida ${ }^{1}$. Vários critérios podem ser utilizados para a escolha desta UM, entre eles:

1. UM com menos mobilidade - Neste caso, a ERB consulta qual UM, em área de intersecção está parada a mais tempo. Os dados necessários a esta consulta podem ser facilmente disponibilizados. Para isto, as ERBs podem manter um registro das últimas ERBs utilizadas por

\footnotetext{
${ }^{1} \mathrm{O}$ hand-off é compulsório.
} 
cada UM, assim como o tempo de utilização, ou mesmo manter um registro com o período da última movimentação da UM. Na própria atualização as UMs podem ser ordenadas em ordem decrescente de mobilidade. Estas informações podem ser transferidas entre ERBs quando ocorrem os hand-offs. No entanto a UM escolhida pode conter mais de uma possibilidade de ERB a conectar, neste caso a ERB escolhida será a de menor carga. Cabe salientar que quando dizemos menos mobilidade, estamos querendo dizer a UM que está a mais tempo parada, e não aquela que tem característica de menor movimentação no sistema. A estratégia é apresentada pelo Algoritmo 1.

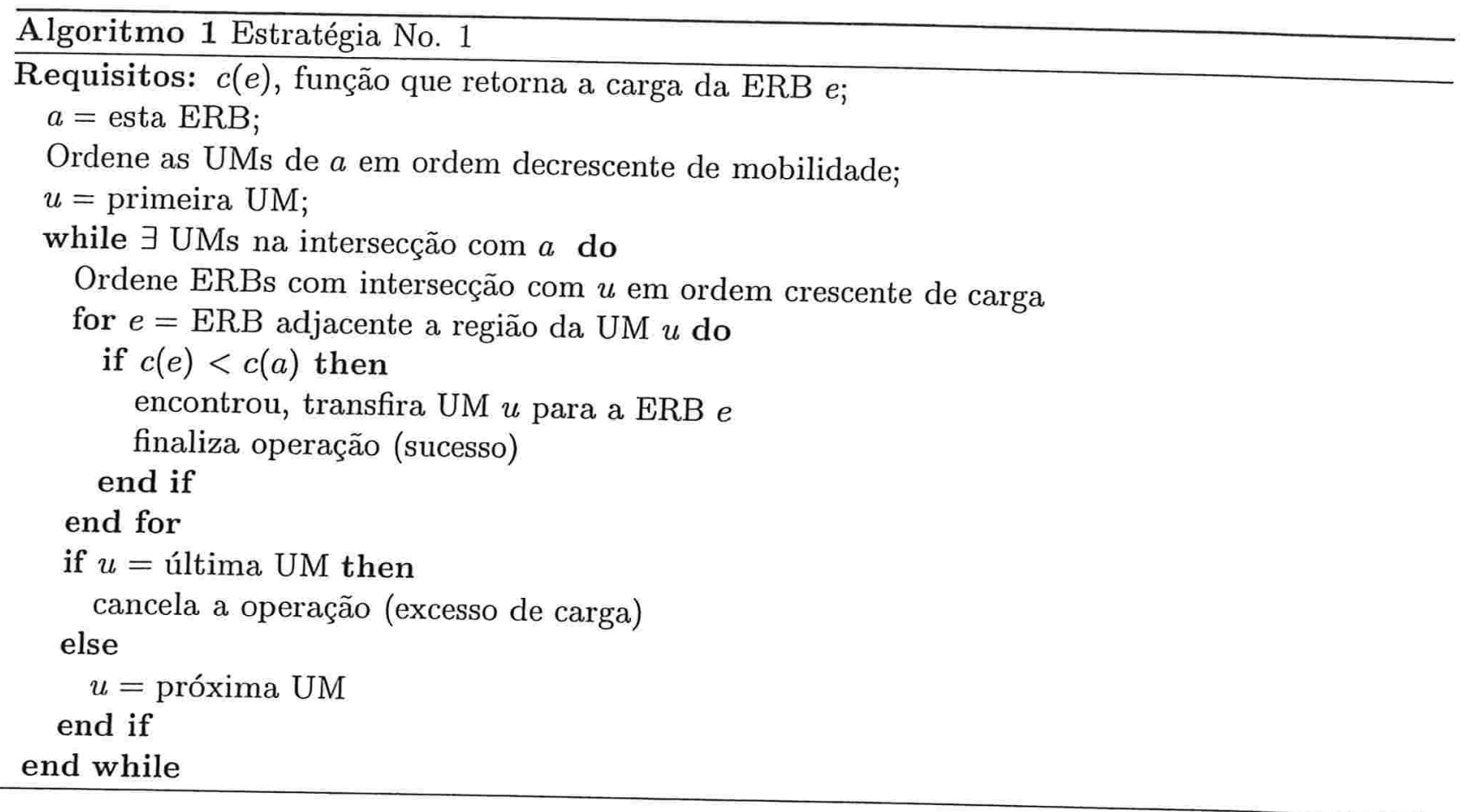

2. ERB adjacente com menor de carga (consideraremos menor carga como menor número de canais ocupados) - Neste caso, a ERB encontra, para todas as UMs em áreas de intersecção, a UM com menos mobilidade, que poderá ser transferida para a ERB adjacente com mais canais disponíveis. Cabe salientar, que primeiramente escolhe-se a ERB a ser transferida, depois escolhe-se a UM. Esta estratégia é dada pelo Algoritmo 2.

3. Rodízio de carga entre ERBs adjacentes - Para isto, a ERB escolhe entre as UMs em área de intersecção, a ERB adjacente abaixo do limite àquela que a mais tempo não recebe UMs. Desta forma é feito para cada ERB, um rodízio das ERBs adjacentes. No entanto, a ERB escolhida pode conter mais de uma possibilidade de UMs, neste caso a UM escolhida será a com menos mobilidade. Sua funcionalidade é apresentada pelo Algoritmo 3. 

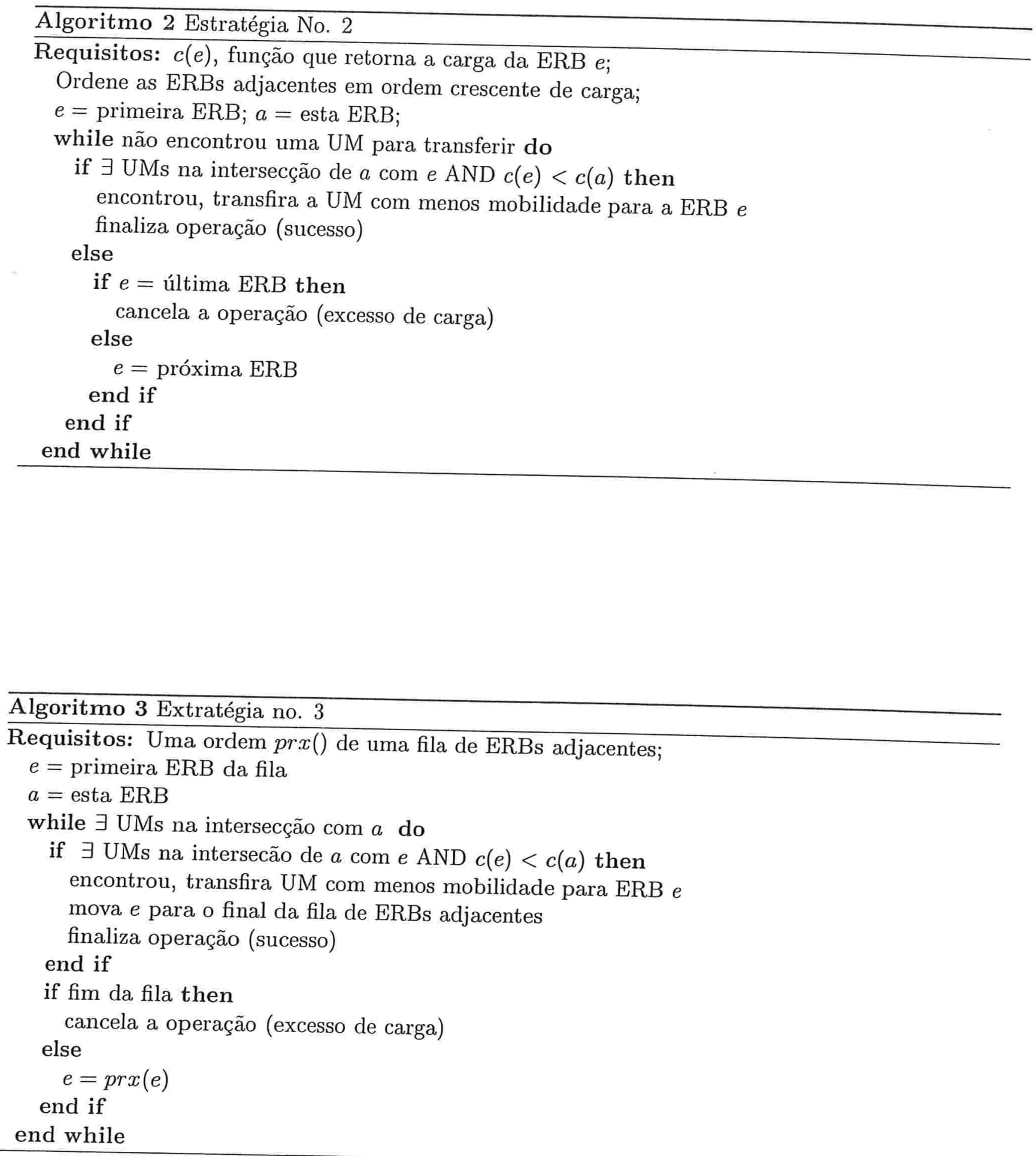
Para todos os algoritmos pode-se adequar um limiar de transferência de carga, de modo que os testes do tipo $c(e)<c(a)$ sejam substituidos por $c(e)+K<c(a)$. O melhor valor de $K$ deve ser determinado experimentalmente.

Apesar do modelo com intersecções poder ser usado tanto com alocação fixa, como dinâmica de canais, neste trabalho usa-se como base a alocação fixa de canais. O emprego de alocação dinâmica não mudaria os algoritmos apresentados nesta dissertação, entretanto é necessária uma adaptação.

\subsubsection{Balanceamento permanente}

Neste caso, o balanceamento ocorre todo o tempo, sempre que uma ERB detecta que tem $k$ UMs a mais do que uma de suas adjacentes. A escolha da UM a ser, ou a serem, transferidas podem seguir os mesmos critérios anteriores.

\subsection{Comparação das estratégias}

Foram apresentados 3 estratégias que se propõem a realizar os objetivos desta dissertação. Ainda poderiam ser aplicadas várias outras estratégias, no entanto, baseamos nos fatores e hipóteses apresentados neste capítulo para elaborar as estratégias.

Devido a dificuldade de efetuarmos uma comparação analítica das estratégias vistas, o comportamento delas serão vistos nos resultados das simulações, onde estão as análises pertinentes.

Para que as simulações sejam válidas será necessário um modelo próximo a realidade. Dentro deste objetivo, no próximo capítulo veremos os modelos de mobilidade adotados. 


\title{
Capítulo 6
}

\section{A Mobilidade}

\begin{abstract}
A mobilidade dos usuários interfere diretamente na qualidade do serviço oferecido, pois dependendo das condições e requisições de serviço das unidades móveis, a disponibilidade de recursos pode variar conforme a localizaçẫo onde se encontra a unidade. Neste capítulo são apresentados os motivos e necessidades de um modelo de mobilidade. Também é apresentado o modelo adotado na simulaçẫo realizada para comparação das estratégias
\end{abstract}

\subsection{Necessidade de padrões de mobilidade}

Na computação móvel, existe a possibilidade das unidades móveis poderem se movimentar, sob a restrição de ficarem dentro de um espaço onde a comunicação seja permitida, caso contrário a UM fica sem conexão com a rede. Desta forma, o usuário não fica limitado a uma posição fixa no espaço, possibilitando o surgimento de novas aplicações que aproveitam esta característica. Mas para isso, é conveniente tentar prever o comportamento dos usuários de forma realista, porém isto não é uma tarefa tão simples. Muitos são os fatores que interferem nesse comportamento, que vão desde características físicas, culturais e sociais do usuário, como também os períodos do dia, posição geográfica, dentre outros fenômenos.

A mobilidade dos usuários interferem diretamente na qualidade do serviço oferecido. Por exemplo, uma grande concentração de unidades em uma região pode implicar em falta de recursos, ou mesmo a unidade pode migrar para uma região onde o recurso ainda não está disponível. Portanto, reservar ou preparar recursos da infra-estrutura para oferecer um serviço de qualidade as unidades móveis é um desafio a ser superado, principalmente neste contexto de constante mudanças. 
Há então a necessidade de padrões de mobilidade nas comunicações móveis, para que possamos prever vários aspectos da mobilidade, assim obtendo um maior conhecimento sobre as necessidades de recursos do sistema. A respeito dos aspectos envolvidos, em [23] são definidos três subgrupos: aspectos do gerenciamento de localização, aspectos no gerenciamento do recurso de radiotransmissão e aspectos de propagação de radiotransmissão.

Aos aspectos do gerenciamento de localização estão associados questões como localização de um unidade móvel no sistema, ou também a estratégias de localização de dados, os quais podem estar distribuídos pelo sistema. Desta forma as estratégias podem determinar qual será a forma mais eficiente de se obter um dado. A mesma analogia pode ser empregada em questões de carga de requisições ao banco de dados, o qual pode ser distribuído, ou segmentado, para atender a demanda do sistema móvel.

Aos aspectos do gerenciamento do recurso de radiotransmissão estão associados a questões como o planejamento do layout da célula, que pode possuir maiores, ou menores, áreas de intersecção entre as células. Outro ponto seria relativo aos esquemas de alocação de canais (Capítulo 3). Ainda podemos considerar as técnicas de múltiplo acesso (TDMA, CDMA, etc.), estimação da capacidade do sistema, além da sinalização, e carga do tráfego.

Aos aspectos do gerenciamento da propagação de radiotransmissão estão associados quesitos como variação da potência do sinal de rádio utilizado pela unidades móveis e ERBs. Algoritmos de decisão de hand-off, os quais podem decidir em qual ERB uma unidade pode se conectar em um dado momento.

\subsection{Modelo de mobilidade genérico}

A Figura 6.1 descreve um modelo genérico de mobilidade composto pelo seguintes conjuntos:

- Um conjunto de parâmetros de entrada $(C e)$.

Consiste em toda a informação necessária para prover meios para o modelo aplicar a ação de mobilidade nas unidades. Para isso alguns conjuntos tem que ser repassados ao modelo:

- Um conjunto de pontos, $G$, os quais representam as possíveis localizações das unidades.

- Um conjunto de unidades, $P$, os quais constituem a população do modelo.

- Um conjunto de intervalos de tempo, $T$, constituindo o período de tempo total do modelo.

- Um conjunto de parâmetros de saída $(C s)$. 


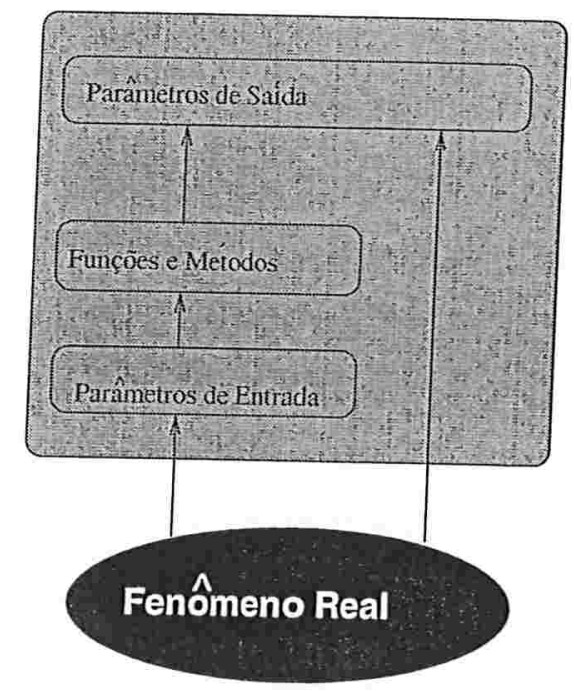

Figura 6.1. Representação de modelo genérico.

Consiste em um conjunto de funções que podem por exemplo: prover a localização de uma unidade $p$ sobre um conjunto $G$ para cada instância de tempo no conjunto $T$. Isto é, o $C s$ é um conjunto de funções $g_{p}$ tal que: $g_{p}(t) \in G, \forall p \in P, \forall t \in T$. Onde $g_{p}(t)$ é a localização de uma unidade $p$ no tempo $t$ sobre o conjunto $G$.

Entretanto categorizar os conjuntos sem nenhuma delimitação pode se tornar impraticável, desta forma podemos agrupar os conjuntos em:

- População $\left(P^{\prime}\right)$ : Onde a população pode ser agrupada em classes (pedestres, passageiros de veículo, estudantes, etc.) baseando-se no comportamento de mobilidade de cada grupo.

- Área Geográfica $\left(G^{\prime}\right)$ : Onde a região de estudo é segmentada em regiões que possuem características semelhantes quanto a mobilidade (Rural, Urbana, Central, etc.).

- Zonas Temporais $\left(T^{\prime}\right)$ : Onde podemos dividir o tempo em zonas, que possuem características semelhantes quanto a movimentação da unidades (Horas de rush, hora do almoço, etc.).

Desta forma teremos comportamentos semelhantes para funções $g_{p}(t), \forall p \in P^{\prime}, \forall t \in T^{\prime}$, e também concentrações semelhantes segundo as diferentes regiões de $G^{\prime}$.

Os conjuntos de parâmetros de saída podem conter outras informações além da localização. Em casos de avaliação de alguns aspectos, podem ser necessário avaliar o valor de um aspecto 
com relação a uma unidade $p$, em uma região do conjunto $G^{\prime}$, num dado instante $t$.

\subsection{Modelos de mobilidade}

Kelvin, et al. [11] mencionam que a maioria dos modelos da literatura fazem simplificações para facilitar a análise da mobilidade. Por exemplo, o caso onde o autor assume que o número de usuários numa célula permanece sempre constante. Em outro caso, a velocidade do usuário é considerada constante, além da direção da movimentação dos usuários ser modelada como sendo uniformemente distribuída entre $[0,2 \pi]$.

Essas simplificações tornam os cálculos dos parâmetros de qualidade da rede mais simples, mas podem distanciar-se muito das previsões dos valores no mundo real. Nesta dissertação será utilizado um modelo, inicialmente proposto em [2] que procura classificar a mobilidade em diferentes perfis, a fim de cobrir os mais variados tipos de comportamentos dos usuários.

\subsubsection{Um modelo baseado em perfis}

O ambiente a ser modelado é dividido em três dimensões, como mostrado na Figura 6.2:

- Dimensão pessoal: descreve classes de usuários com diferentes comportamentos em relação à mobilidade;

- Dimensão temporal: descreve o perfil dos diferentes períodos temporais de acordo com as características de mobilidade de cada período;

- Dimensão espacial: descreve o perfil de cada tipo de região em relação à "atração" exercida sobre os usuários.

Para cada combinação entre as dimensões pessoal, temporal e espacial é associado um perfil de mobilidade, por exemplo: um determinado tipo de usuário (dimensão pessoal), em uma determinada hora do dia (dimensão temporal), em uma região específica (dimensão espacial), possui um certo perfil de mobilidade.

\section{Dimensão Pessoal}

Nesta dimensão o modelo divide os usuários em grupos que apresentam um comportamento semelhante em relação às possíveis regiões de movimentação ao longo do dia.

Os seguintes grupos são considerados: 


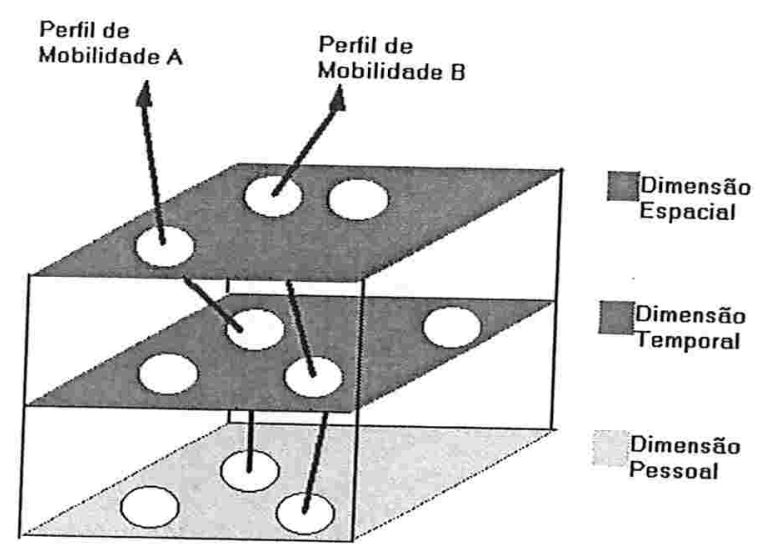

Figura 6.2. Modelo de mobilidade multidimensional baseado em perfis.

Usuário Trabalhador Comum - um indivíduo que acorda de manhã, vai para o trabalho onde passa a maior parte do dia, e retorna para casa à noite, recomeçando o ciclo novamente no dia seguinte. Podendo realizar pequenas movimentações entre a hora do início e fim do trabalho, como na hora do almoço;

Usuário de Alta Mobilidade - passa a maior parte do dia se movimentando de um lugar para outro. Essa característica é típica de certas profissões, como por exemplo, representantes de vendas, corretores de seguros, fiscais, motoristas, etc;

Usuário Residencial - indivíduo que não trabalha, passa a maior parte do tempo em casa, realizando movimentações esporádicas durante o dia. Podendo permanecer desde alguns minutos até várias horas no local visitado, como em bancos, lojas, shopping centers, supermercados ou praias, por exemplo.

2. Dimensão Temporal

A mobilidade é altamente influenciada pelo horário. Durante as primeiras horas da manhã, por exemplo, há um maior fluxo de usuários das suas residências para os locais de trabalho. Já no final da tarde e início da noite, o fluxo de usuários trabalhadores é grande no sentido contrário, do trabalho para as residências, ou para as áreas de lazer. Assim, a dimensão temporal é caracterizada por zonas temporais, nas quais os usuários possuem um certo comportamento. A Tabela 6.1 mostra as zonas temporais de uma região metropolitana brasileira típica.

\section{Dimensão Espacial}

Cada célula é classificada de acordo com as características da região onde ela se localiza. Cada 


\begin{tabular}{|l|l|l|}
\hline Zonas & Horário & Descrição \\
\hline Zona 1 & 06:00 às 08:00 & Hora do rush (manhã) \\
Zona 2 & 08:00 às 12:00 & Horário comercial de trabalho \\
Zona 3 & 12:00 às 14:00 & Horário de almoço \\
Zona 4 & 14:00 às 18:00 & Horário comercial de trabalho \\
Zona 5 & 18:00 às 20:00 & Hora do rush (noturna) \\
Zona 6 & 20:00 às 24:00 & Horário de descanso ou lazer \\
\hline
\end{tabular}

\section{Tabela 6.1. Zonas temporais}

tipo de célula exerce um certo "poder de atração" sobre os usuários durante um determinado intervalo de tempo. Uma célula localizada numa região residencial, por exemplo, vai atrair mais usuários nas primeiras horas da manhã (Zona 1) ou à noite (Zonas 5 e 6). Já uma célula localizada no centro comercial da cidade vai atrair um grande número de usuários no horário do expediente (Zonas 2 e 4). De acordo com o perfil da região podemos classificar as células quanto a atração exercida sobre os usuários como: Residencial (R), Trabalho (T), Banco (B), Shopping (S) ${ }^{1}$ e Lazer (L).

\section{Definição dos perfis de mobilidade}

$\mathrm{Na}$ implementação do modelo realizada neste trabalho, cada perfil de mobilidade é definido utilizandose informações das dimensões e pode ser especificado através de três parâmetros: o tempo de permanência do usuário numa célula pela qual está passando ( $T_{\text {res }}$ - cell residence time); um algoritmo que possa prever a célula para qual o indivíduo deseja se movimentar; e o tempo de permanência do usuário na célula de destino $\left(T_{d}\right)$.

O $T_{\text {res }}$ está relacionado com a velocidade do usuário móvel e o tamanho das células, este é o tempo que o usuário leva para cruzar a célula. A decisão da célula de destino do usuário é outro ponto muito importante na definição do perfil de mobilidade. Esta escolha está diretamente relacionada com a geração de procedimentos de hand-offs, cuja probabilidade de falha é um parâmetro determinante da QoS do sistema.

Neste trabalho, a célula de destino não corresponde necessariamente à próxima célula, mas a

\footnotetext{
${ }^{1} \mathrm{O}$ nome Shopping foi utilizado conforme estabelecido no artigo de origem, mesmo que o mais conveniente seja Comercial
} 
qualquer célula dentro da área de cobertura. Um usuário do tipo trabalhador comum, por exemplo, no horário entre 8:00 e 12:00 horas da manhã, com grande probabilidade, sairá da sua residência (célula atual) e se deslocará para sua área de trabalho (célula de destino) que pode estar localizada a uma longa distância da sua residência.

O algoritmo que decide a célula destino do usuário utiliza informações das três dimensões (pessoal, temporal, espacial) para tomar uma decisão. O algoritmo é baseado em uma matriz de probabilidades dos pontos de atração para cada tipo de usuário definido na dimensão pessoal.

Esta matriz associa a cada tipo de célula da dimensão espacial uma probabilidade de atração de acordo com a zona temporal. Por exemplo, um usuário trabalhador comum na zona temporal 2 tem uma maior probabilidade de se movimentar para uma área de trabalho. Para cada tipo de usuário é definida uma matriz de probabilidades dos pontos de atração. As Tabelas 6.2 e 6.3 representam exemplos de matrizes para os usuários classificados no tipo residencial, e trabalhador, respectivamente.

\begin{tabular}{|l|c|c|c|c|c|}
\hline Zonas Temporais & Residencial(R)\% & Trabalho(T)\% & Banco(B)\% & Shopping(S)\% & Lazer(L)\% \\
\hline Zona 1 & 90 & 0 & 0 & 0 & 10 \\
\hline Zona 2 & 20 & 30 & 40 & 10 & 0 \\
\hline Zona 3 & 40 & 10 & 40 & 10 & 0 \\
\hline Zona 4 & 40 & 10 & 10 & 30 & 10 \\
\hline Zona 5 & 50 & 0 & 0 & 20 & 30 \\
\hline Zona 6 & 50 & 0 & 0 & 20 & 30 \\
\hline
\end{tabular}

Tabela 6.2. Probabilidade dos perfis de mobilidade para os usuários residênciais.

Os valores das probabilidades são parâmetros de entrada para a simulação e podem ser alterados de acordo com as características da região, e dos usuários, que estão sendo modelados. Para o usuário de alta mobilidade, a matriz de probabilidades possui valores iguais entre si, pois se pretende modelar nesse caso, um comportamento realmente aleatório, como a movimentação de um motorista de taxi, por exemplo. Assim, considera-se que a probabilidade de deslocamento para qualquer célula dentro da topologia é a mesma. O algoritmo escolhe aleatoriamente uma célula qualquer dentro da topologia como o destino da UM no início de cada movimentação.

Depois de definido o destino, o próximo passo é definir a rota que o usuário vai seguir para chegar ao destino, ou seja, as próximas células pelas quais ele vai passar na sua jornada. A partir 


\begin{tabular}{|l|c|c|c|c|c|}
\hline Zonas Temporais & Residencial(R)\% & Trabalho(T)\% & Banco(B)\% & Shopping(S)\% & Lazer(L)\% \\
\hline Zona 1 & 90 & 0 & 0 & 0 & 10 \\
\hline Zona 2 & 10 & 80 & 10 & 0 & 0 \\
\hline Zona 3 & 40 & 10 & 30 & 20 & 0 \\
\hline Zona 4 & 10 & 80 & 5 & 5 & 0 \\
\hline Zona 5 & 50 & 0 & 0 & 20 & 30 \\
\hline Zona 6 & 70 & 0 & 0 & 20 & 10 \\
\hline
\end{tabular}

Tabela 6.3. Probabilidades dos perfis de mobilidade para os usuários trabalhadores.

da topologia simulada são definidas várias rotas através das quais o usuário pode chegar a um mesmo destino. O simulador poderá utilizar uma tabela com todas as rotas possíveis.

Estas rotas são parâmetros de entrada do simulador e podem ser escolhidas livremente na definição do exemplo.

Definida a célula de destino do usuário, o simulador procura a primeira rota que o leve ao destino escolhido. O último parâmetro que caracteriza o perfil de mobilidade é o tempo de permanência na célula destino $\left(T_{d}\right)$. Quando uma UM chega ao seu destino, ela geralmente deseja realizar uma atividade qualquer, o que levará um tempo maior do que simplesmente atravessar as células. Este comportamento é simulado utilizando o tempo $T_{d}$ como uma variável aleatória dentro de uma faixa de tempo conforme a classe do usuário. Finalizado esse tempo, o usuário inicia um novo processo de movimentação com a escolha de um novo destino. 


\title{
Capítulo 7
}

\section{O Simulador}

\begin{abstract}
Neste capítulo veremos alguns simuladores para computação móvel, os quais poderiam ter sido utilizados para implementação do modelo sugerido. Porém, pelos motivos relatados neste capítulo, optou-se pela implementação de um simulador próprio. A definição do modelo adotado seus requisitos e abstrações, assim como o detalhamento técnico da implementação do simulador também estão presentes.
\end{abstract}

\subsection{Avaliação inicial}

No início deste trabalho foi necessário realizar um levantamento de simuladores para computação móvel, que pudessem fornecer um ambiente integrado e de fácil implementação para as estratégias propostas nesta dissertação. Muitos simuladores já foram desenvolvidos para computação móvel, e podem ser classificados de acordo com a flexibilidade em: simuladores de rede e simuladores de protocolos.

Simuladores de rede $[4,22]$ são desenvolvidos para simular um ambiente específico de rede e protocolos, em relação a diferentes padrões de topologias ou comportamento dos elementos de rede. Geralmente, os ambientes são simulados em um grau menor de detalhamento, e implementam otimizações baseadas no conhecimento do ambiente simulado, assim permitindo diminuir o tempo de realização da simulação.

Simuladores de protocolos, por outro lado, são implementados para serem flexíveis e permitir a implementação e o teste de protocolos em um ambiente de rede simulado. Devido ao seu caráter 
genérico, muitas das otimizações implementadas nos simuladores de rede não podem ser incorporadas nos simuladores de protocolos, e por isso o tempo de realização da simulação é tipicamente maior. Em contrapartida, a abordagem de implementação desses simuladores permite o uso de abstrações flexíveis e reutilizáveis, na maioria das vezes baseadas em arquiteturas orientadas a objetos.

Entretanto para avaliação inicial selecionamos alguns simuladores previamente avaliados por Ricardo Rocha em [28]: GloMoSim, Ns, e o seu próprio simulador o MobiCS.

\section{- GloMoSim}

O GloMoSim [39] (Global Mobile system Simulator), utiliza uma biblioteca implementada em Parsec [3], uma linguagem de simulação paralela baseada na linguagem C. O núcleo do Parsec implementa uma máquina de simulação de alto desempenho, que utiliza vários protocolos de simulação paralela e distribuída. Essa característica permite a utilização do GloMoSim para a simulação de redes de computação móvel de larga escala. Além disso, Parsec permite tornar a maior parte dos detalhes de simulação transparentes ao programador.

Para programar um protocolo, o usuário deve utilizar o modelo de programação Parsec. Neste modelo, protocolos são implementados em módulos monolíticos chamados entidades. Cada entidade define as mensagens trocadas com as demais entidades e o algoritmo do protocolo, o qual define as ações que devem ser executadas no recebimento de cada mensagem.

Este é um simulador de protocolos que favorece um melhor desempenho da simulação, em detrimento das abstrações de programação, que são limitadas pelo modelo de programação da linguagem Parsec.

- $N s$

O $N s[5,16]$ é um simulador de eventos discretos, flexível e de carácter geral amplamente utilizado para simulação de protocolos de rede. O Ns pode ser utilizado também como um emulador de rede, fazendo com que uma rede simulada se relacione com uma rede real. $\mathrm{O}$ pacote do $N s$ ainda inclui geradores de padrões de falhas, tráfego e topologias de rede, além de uma ferramenta de animação de rede.

O Ns utiliza um modelo de programação em dois níveis: núcleo de simulação, e módulos programados. O núcleo é implementado em $\mathrm{C}++$, que interage com módulos programados em OTcl, uma extensão orientada a objetos de Tcl [25]. O núcleo em $\mathrm{C}++$ implementa a funcionalidade da rede, as primitivas e a máquina de simulação, enquanto os módulos em OTcl 
são utilizados para definir, configurar e controlar as simulações. O Ns adota um modelo de programação dividido, com o objetivo de oferecer um compromisso entre o tempo de execução da simulação e abstrações de programação.

\section{- MobiCS}

Mobile Computing Simulator [28] é um simulador distribuído de eventos discretos que permite prototipagem, teste e avaliação de protocolos distribuídos. O modelo disponibiliza para o usuário dois modos de simulação: o modo determinístico e o modo estocástico. O modo determinístico implementa uma simulação sob um roteiro que descreve o comportamento dinâmico do ambiente simulado. No modo estocástico, um protocolo é submetido a uma simulação exaustiva, conforme um certo padrão de comportamento dos elementos simulados, o qual é definido pelo usuário.

Basicamente, o MobiCs é uma biblioteca Java que implementa todos os objetos necessários para que o usuário programe e simule protocolos. Para criar uma simulação, usuário basicamente implementa as classes que definem os protocolos, o ambiente e o modelo de simulação desejado. Estas classes estendem as classes básicas do MobiCs, que implementam a funcionalidade das várias camadas de software do simulador.

Na Tabela 7.1 são relacionadas as principais diferenças entres os simuladores mencionados.

Os simuladores apresentam várias considerações que nos levaram a escolher a plataforma de testes e simulações.

O GloMosim e $N s$ não permitem a programação de modelos de simulação, sem modificações no código do próprio simulador. Além disso, eles exigem que o programador tenha conhecimento relativo sobre as linguagens e arquiteturas imposta pelo ambiente de desenvolvimento dos simuladores.

As estratégias utilizadas neste trabalho se enquadram em protocolos das camadas baixas do modelo de padronização ISO (Camada Física, Enlace de Dados, e Rede). Apesar de GloMoSim e $N s$ serem desenvolvidos para permitir a simulação de protocolos de diferentes camadas, eles têm sido utilizados sobretudo para a simulação de protocolos nas camadas de transporte e de rede. Sendo que para utilizá-los em outras camadas é necessário a configuração de vários módulos, os quais não tinham relação direta com as estratégias. Já o MobiCS não permite uma simulação eficiente nesta classe de protocolos, uma vez que baseia-se em abstrações que encapsulam detalhes de comunicação entre máquinas. Além disso, o MobiCs apresenta como abstração que as células não possuiam 


\begin{tabular}{|l|l|l|l|}
\hline & GloMoSim & Ns & MobiCS \\
\hline Aspecto avaliado & Protocolos & Protocolos & Protocolos / Algoritmos \\
\hline Objetivo & Análise de Desempenho & Análise de Desempenho & $\begin{array}{l}\text { Análise de Desempe- } \\
\text { nho, Prototipagem, } \\
\text { Teste }\end{array}$ \\
\hline $\begin{array}{l}\text { Tipo Algoritmo / Pro- } \\
\text { tocolo }\end{array}$ & Transporte & Transporte & Protocolos Distríbuídos \\
\hline Implementação & Parsec & OTcl / C++ & Java \\
\hline $\begin{array}{l}\text { Abstrações e Modulari- } \\
\text { zação }\end{array}$ & Limitada, Funções & OO & OO \\
\hline $\begin{array}{l}\text { Modelos de Simulação e } \\
\text { mobilidade }\end{array}$ & Próprio configurável & Próprio configurável & Programável \\
\hline Extensibilidade & não & & sim \\
\hline
\end{tabular}

Tabela 7.1. Comparação entre diferentes simuladores.

intersecção, o que era absolutamente necessário para a utilização das estratégias proposta nesta dissertação.

Com esta análise inicial, optamos por implementar um software que apenas avaliasse as estratégias deste trabalho, com o intuito de permitir uma maior flexibilidade, este deveria ser implementado através de uma linguagem de programação orientada a objetos.

Inicialmente o software foi desenvolvido em $\mathrm{C}++$, usando o primeiro protótipo foi possível obter alguns resultados relevantes [31]. Entretanto, a necessidade de programação concorrente, e a dificuldade da utilização deste recurso em $\mathrm{C}++$, nos levaram a decisão de implementar o software final em Java:

- Java é uma linguagem de alto nível, permitindo desenvolvimento orientado a objetos, desta forma adequada a prototipagem;

- Java incorpora, em seu próprio mecanismo, a programação de aplicações concorrentes baseadas em threads. Essa é uma característica frequentemente útil em qualquer software para simulação;

- A possibilidade de execução de código Java em diferentes sistemas operacionais permite a 
utilização da simulação em diferentes máquinas com ambientes heterogênios.

Após definida a plataforma de teste das estratégias, alguns requisitos foram estabelecidos para implementação do código.

\subsection{Requisitos e abstrações}

Através da análise inicial, chegou-se a decisão de que o ambiente de simulação deveria ser composto de módulos que representem as condições reais do ambiente de computação móvel. Para isto, alguns requisitos foram estabelecidos, e enquadrados em três módulos principais: Unidade Móvel, Estação Base de Rádio, Ambiente.

Estes módulos representam os componentes do sistema, o qual são apresentados na Figura 7.1

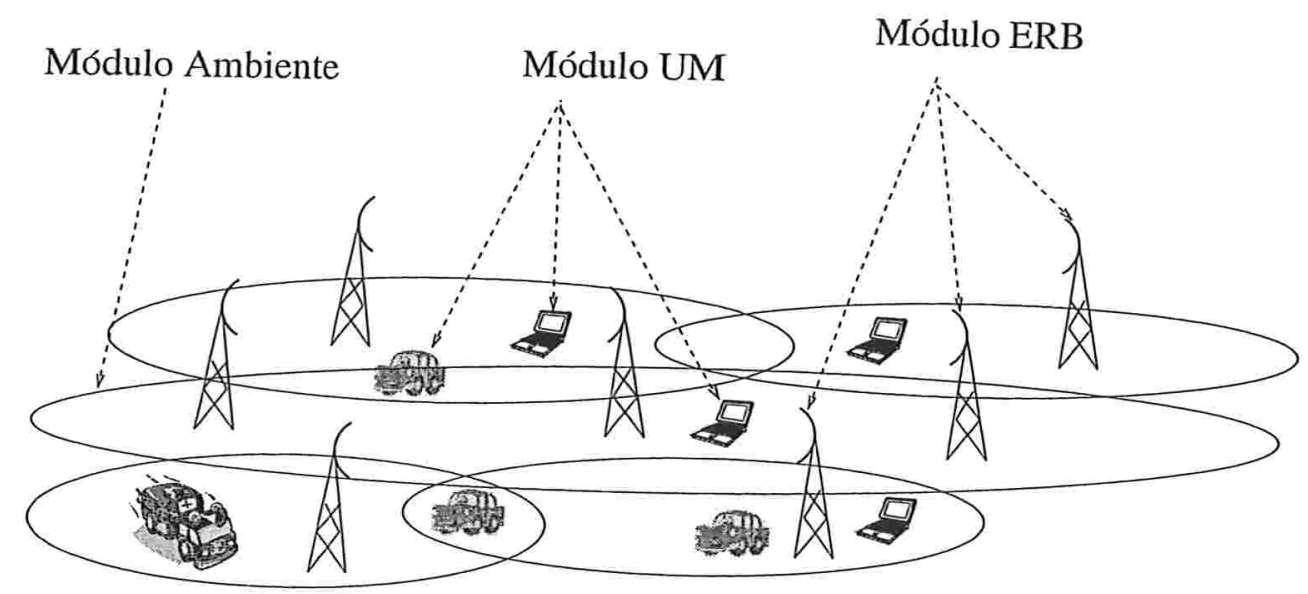

Figura 7.1. Representação dos componentes em módulos do sistema.

\section{Módulo Unidade Móvel}

O componente que representa as funcionalidades e características da unidade móvel dentro do ambiente. Este componente deve ser capaz de:

- Se movimentar de forma independente dentro da área de cobertura;

- Pedir conexão a uma ERB que possua sinal suficiente para obter acesso à rede fixa, assim como solicitar a transição para outra ERB que possua melhor qualidade de sinal;

- Possuir um "Perfil Pessoal" que expresse as características de sua utilização. No Capítulo 6, este perfil é caracterizado como: Trabalhador, Residêncial ou Alta mobilidade. 
2. Módulo Estação Base de Rádio

O componente que possibilita a conexão das UMs à rede fixa. Este componente deve ser capaz de:

- Estar conectada diretamente a rede fixa, servindo de intermediário entre a UM e a rede;

- Possuir canais, os quais podem ser disponibilizados para as UMs estabelecerem conexão a rede fixa;

- Estabelecer técnicas para a alocação de canais, como observadas no Capítulo 3, "Alocação de Canais";

- Possibilitar a implementação das estratégias propostas no Capítulo 5;

- Estabelecer processos que executem os pedidos de transição das UMs (hand-off), tanto para as UMs que estão chegando nesta ERB, quanto para aquelas que estão saindo;

- Catalogar todas as UMs conectadas a ela;

- Possuir um "Perfil Espacial" que expresse as características da região onde a ERB está localizada. No capítulo 6 este perfil é caracterizado como: Banco, Residencial, Lazer, Shopping ou Trabalho.

3. Módulo Ambiente

O componente que representa a região geográfica por onde as UMs se locomovem, e as ERBs estão instaladas. Este componente deve ser capaz de:

- Ser dividido em micro-áreas suficientemente pequenas a ponto de representarem uma posição única caracterizada por linha e coluna;

- Catalogar as ERBs instaladas no sistema;

- Contabilizar os resultados dos "parâmetros de avaliação", os quais serão detalhados no próximo capítulo;

- Possibilitar a geração de um "Perfil Temporal" que expresse as características temporais do sistema. Além de controlar o tempo simulado. No capítulo 6, este perfil é caracterizado pelas zonas temporais, e expresso pela Tabela 6.1.

Além destes requisitos foi necessário estabelecer algumas abstrações para a codificações do software, como: 
- As unidades somente se locomovem dentro da área delimitada pelo ambiente de simulação, para isso as origens e destinos das UMs sempre estão sob estas restrições;

- As unidades podem se desconectar do sistema por falta de canais na ERB, a qual está solicitando conexão, ou por nível insuficiente de sinal da ERB a qual está conectada. Assim, não estão sendo consideradas as interferências geradas fora do sistema celular, que podem até causar desconexões do sistema. É fato que estas interferências existem no mundo real, porém foram desconsiderados para uma avaliação exclusiva das estratégias empregadas no sistema;

- A cobertura da ERB não se altera durante o tempo de simulação. Mesmo sabendo que a cobertura se altera por vários fatores, isso não prejudica as estratégias de alocação de canais, como detalhado na Seção 5.2 .

\subsection{Implementação}

Nesta seção são apresentados os principais aspectos técnicos que foram utilizados no desenvolvimento do software. A versão final do software foi elaborada em Java versão 1.4 da Sun [34]. O mesmo foi elaborado dentro dos conceitos de orientação a objeto, com a utilização de programação concorrente, como definido na fase de requisitos. O software é composto de várias classes, sendo as principais delas as que representam os três módulos determinados na Seção 7.2.

No Apêndice A, é apresentado o diagrama de classes do simulador.

As classes "Ambiente" (Módulo Ambiente), "UM" (Módulo Unidade Móvel), "ERB" (Módulo Estação Base de Rádio) atendem as determinações dos requisitos apresentados na Seção 7.2, além desses, vale a pena destacar a classe "Simula", o qual determina a ordem dos acontecimentos, o controle do tempo simulado, as posições das ERBs, e o início e fim da simulação.

\subsubsection{Classe: Ambiente}

A classe Ambiente representa a região geográfica do sistema. A área de cobertura total do sistema é dividida em pequenas regiões, micro-áreas (classe microarea). Sendo que nesta pequena região podem estar localizadas UMs ou ERBs. No entanto, a ERB ao ser "instalada" em uma micro-área propaga o sinal de transmissão por várias micro-áreas adjacentes.

Cada ERB gera sinal de transmissão sobre uma região, sendo que a diminuição do sinal de cada ERB varia conforme a distância, dentre outros aspectos [24]. Entretanto para facilitar a configuração do ambiente de simulação sem prejudicar os resultados, neste simulador foi considerado a degradação 
do sinal como linear em relação a distância. Como ilustração, a Tabela 7.2 mostra a propagação de sinal de uma ERB "instalada" na coordenada $(5,5)$ com potência de alcance equivalente a distância de 5 micro-áreas.

\begin{tabular}{l|lllllllll} 
& 1 & 2 & 3 & 4 & 5 & 6 & 7 & 8 & 9 \\
\hline 1 & 0 & 0 & 0 & 0 & 1 & 0 & 0 & 0 & 0 \\
2 & 0 & 0 & 1 & 1 & 2 & 1 & 1 & 0 & 0 \\
3 & 0 & 1 & 2 & 2 & 3 & 2 & 2 & 1 & 0 \\
4 & 0 & 1 & 2 & 3 & 4 & 3 & 2 & 1 & 0 \\
5 & 1 & 2 & 3 & 4 & 5 & 4 & 3 & 2 & 1 \\
6 & 0 & 1 & 2 & 3 & 4 & 3 & 2 & 1 & 0 \\
7 & 0 & 1 & 2 & 2 & 3 & 2 & 2 & 1 & 0 \\
8 & 0 & 0 & 1 & 1 & 2 & 1 & 1 & 0 & 0 \\
9 & 0 & 0 & 0 & 0 & 1 & 0 & 0 & 0 & 0
\end{tabular}

Tabela 7.2. Propagação do sinal de uma ERB em $(5,5)$.

Esta classe também permite a configuração do modelo de mobilidade adotado, através possibilidade de manipulação dos valores das Tabelas de Probabilidades 6.2 e 6.3, inclusas nesta classe.

\subsubsection{Classe: UM}

Esta classe representa as funcionalidades e características da unidade móvel dentro do ambiente móvel. No ambiente é inserida uma certa quantidade de unidades móveis, que estão divididas em perfis pessoais. O percentual de cada perfil, neste trabalho é o mesmo apresentado em [2] e expresso pela Tabela 7.3 .

\begin{tabular}{|l|l|}
\hline Perfil Pessoal & Percentual populacional \\
\hline Residêncial & $15 \%$ \\
\hline Trabalhador & $60 \%$ \\
\hline Alta mobilidade & $25 \%$ \\
\hline
\end{tabular}

Tabela 7.3. Percentual populacional de unidades móveis.

Dentre algumas características podemos destacar a capacidade da unidade movimentar-se dentro 
da região delimitada. Neste contexto, o modelo de mobilidade apresentado na Seção 6.3 .1 foi utilizado para caracterizar o movimento da unidades. Em linhas gerais, o algoritmo 4 representa a sistemática de geração de mobilidade.

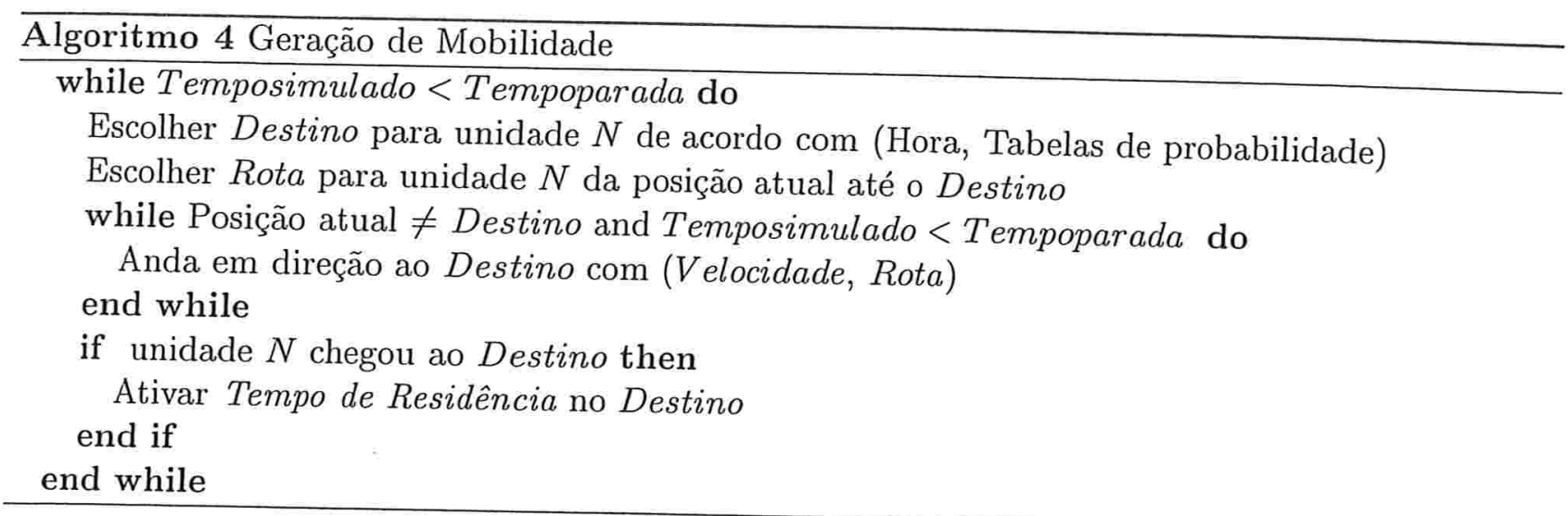

Onde:

- Tempo simulado

Variável do sistema que determina o tempo atual do sistema. Ele é medido em segundos, e controlado pela classe Simula.

- Tempo parada

Variável do sistema que indica o tempo limite (fim da simulação). O valor utilizado para os testes é equivalente a 24 horas.

\section{- Destino}

É composto por linha e coluna, e residente dentro da região delimitada na simulação. A linha, coluna determina qual micro-área a unidade $N$ estará ao chegar ao seu destino. A escolha do Destino é baseada no perfil de mobilidade da unidade, e para isso são utilizadas as informações dos perfis como: Perfil Temporal - baseado no Tempo simulado; Perfil Pessoal - o qual é determinado na criação da classe UM; Perfil Espacial - determinado pela característica da região onde as ERBs estão "instaladas". Estas característica são submetidas à tabela de probabilidade do perfil da unidade $N$, resultando na escolha da ERB destino, mais precisamente uma micro-área dentro da cobertura desta ERB.

- Rota 
A rota determina por quais pontos a unidade $N$, deverá passar no trajeto da posição atual até o Destino. A unidade percorre estes pontos considerando sua Velocidade, desta forma sabe-se o tempo que a unidade $N$ passa em cada micro-área. Entretanto para esta dissertação, a tabela de rotas não foi utilizada, sendo este um dos trabalhos futuros. No lugar desta, a unidade se movimenta em linha reta até a célula destino.

\section{- Velocidade}

A velocidade das unidades é uniformemente distribuída entre $40 \mathrm{~km} / \mathrm{h}$ e $80 \mathrm{~km} / \mathrm{h}$. Estes valores correspondem a variações de velocidade entre usuários que utilizam o sistema de transporte público e particular na maioria das cidades brasileiras. Neste estudo não levamos em consideração os pedestres.

\section{- Tempo de Residência}

Geralmente uma unidade móvel é levada com seu usuário da origem até o Destino, e ficam residente neste destino por algum tempo. Este tempo vária com o perfil pessoal de cada unidade. A Tabela 7.4 encontrada em [23] é utilizada no simulador, e apresenta os valores do tempo de permanência no Destino $\left(T_{d}\right)$ mais comuns para cada perfil.

\begin{tabular}{|l|c|c|}
\hline Perfil Pessoal & Tempo mínimo(s) & Tempo máximo(s) \\
\hline Residêncial & 1800 & 10800 \\
\hline Trabalhador & 900 & 10800 \\
\hline Alta mobilidade & 1 & 900 \\
\hline
\end{tabular}

\section{Tabela 7.4. Tempo de permanência no destino.}

A classe UM ainda tem a possibilidade de se conectar ou de se desconectar do sistema.

\subsubsection{Classe: ERB}

Esta classe representa a estação base de rádio que é responsável por fornecer acesso das unidades móveis a rede fixa. Para isso a ERB fornece canais e formas de compartilhamento destes canais. As ERBs seguem como base a alocação fixa de canais com distribuição homogênea, isto é, todas as ERBs possuem o mesmo número de canais. Para esta simulação, um conjunto de configurações foram adotadas: 
- Número de canais: Foram disponibilizados 30 canais para cada ERB;

- Potência de alcance (transmissão): Cada ERB transmite a uma potência de alcance igual a distância de 21 micro-áreas. A propagação do sinal é denotada pela Tabela 7.2, levando em consideração as devidas proporções;

- Nível mínimo de sinal: É adotado que um sinal abaixo do valor 2, obriga a mudança da UM para uma ERB com maior qualidade de sinal para se manter a conexão. Caso não exista outro sinal disponível a conexão é interrompida;

- Tamanho da célula: Cada micro-área possui forma quadrática e possui 100 metros de largura, considerando a potência de transmissão da ERB igual 21, esta célula fica aproximadamente com um raio de $2,1 \mathrm{Km}$. As quais são de tamanho típico de regiões metropolitanas;

- Número de identificação: Cada ERB possui um identificador único dentro do sistema;

- Classe da ERB: Cada ERB possui uma classificação quanto as características da região onde está situada. Esta informação é a principal fonte para formar o perfil espacial do modelo de mobilidade adotado.

O tipo de alocação de canais adotada é a alocação fixa, além disso as 3 novas estratégias detalhadas no Capítulo 5, "Modelo Sugerido", também são implementadas nesta classe.

O controle do hand-off também é uma das funções da classe ERB, para isso as requisições de hand-off são enfileiradas, e processadas por uma thread que é criada no momento da "instalação" da ERB. Este processo entra em ação assim que é inserida uma requisão na fila de hand-offs e fica inativo quando a fila está vazia. Durante o hand-off é necessária a disponibilidade dos canais na nova ERB para a UM que está migrando. É neste momento que as estratégias entram em operação. Além disso, é necessário liberar o canal que estava sendo usado na antiga ERB.

\subsubsection{Classe: Simula}

Apesar de não se tratar de uma das classes principais, esta tem grande relevância na simulação, sendo o ponto inicial de execução do simulador (método main). Nesta são instanciadas todas classes principais.

Primeiramente é instanciada a classe Ambiente com a quantidade de micro-áreas utilizadas o simulador. Posteriormente as ERBs são "instaladas" em coordenadas específicas e logo após são instanciadas as unidades (classe UM). 
Inicialmente, as UMs são posicionadas aleatoriamente nas micro-áreas, e posteriormente seguem o modelo de mobilidade estabelecido.

A classe Simula, após instanciar todas classes principais, entra em um laço que ativa o método Mobilidade da classe UM, o qual permite a unidade atender cada passo do padrão de mobilidade. Além disso, a cada passo, do laço, o Tempo simulado é incrementado, e então ao final de 24 horas de tempo simulado o processo é finalizado.

\subsubsection{Outras classes auxiliares}

Além das classes principais, outras classes e interfaces são implementadas para dar suporte ao simulador.

Mencionamos as classes Semaphore, ThreadDeHandOff, ItemdaFila, como parte integrante do núcleo de processamento de requisições de hand-off. Ao se criar um ERB, ela inicia uma Thread (ThreadDeHandOff), responsável por retirar itens de uma fila de requisições de hand-off (ItemdaFila), e realizar o processamento necessário. Porém este processo fica inativo, enquanto não há elementos na fila, o qual é sinalizado pelo uso da classe Semaphore. E finalmente, a classe NoNegro que é a representante do grafo de adjacências, descrito no Capítulo 5. 


\section{Capítulo 8}

\section{Simulação}

Neste capítulo são apresentados os resultados das simulações que analisam o funcionamento das estratégias propostas no capítulo 5. Para isto, diversos parâmetros de avaliação foram utilizados como base, para determinar quais são as configurações mais indicados para cada tipo de estratégia, assim como apresentar suas vantagens e desvantagens.

\subsection{Parâmetros de avaliação}

No intuito de avaliar as estratégias propostas, alguns parâmetros de avaliação podem ser considerados. A seguir veremos os parâmetros utilizados para verificar o funcionamento de cada estratégia.

- Quantidade de Novas Conexões.

Determina a quantidade de UMs que se conectaram ao sistema. Idealmente, todas as UMs não deveriam ter problemas para se conectar ao sistema, entretanto na prática isto não acontece. Quando uma UM requisita uma nova conexão, ela solicita a ERB um canal para efetivá-la, mas por falta de disponibilidade de recursos (canais) a solicitação pode ser recusada. Este acontecimento é denotado como bloqueio de novas conexões.

- Bloqueios de hand-off

Ocorrem pela falta de canais durante a transição da unidade móvel de uma ERB, que ao se movimentar entra em uma área coberta por outra ERB. Entretanto, essa ERB pode não possuir recursos disponíveis para realizar a transferência da conexão, o que provoca a interrupção da comunicação. 
- Tráfego de Controle

A carga de tráfego de controle, é outro aspecto bastante representativo, ele determina o nível de tráfego que o algoritmo insere no sistema, para controlar a alocação dos canais. No nosso caso, este tráfego é gerado principalmente pelos hand-offs adicionais provenientes do balanceamento. Ainda existe outro fator de tráfego gerado pelas estratégias, pois existe uma solicitação de informação sobre as cargas das ERB adjacentes para decidir sobre o balanceamento. Esta informação traféga pela rede fixa, gerando um tráfego adicional. Porém por se tratar de um tráfego pequeno, ele não será considerado nas análises dos resultados.

- Quantidade de bits transmitidos segmentados por ERB

Toda unidade móvel, enquanto estiver conectada ao sistema, transmite dados pela rede fixa usando a ERB como intermediária. No entanto, cada ERB pode conter um número diferente de unidades conectadas, conseqüentemente cada ERB intermedia quantidades diferentes de bits. Como nesta simulação foi adotado que todas a unidades transmitem a uma mesma taxa, quanto mais balanceado estiver o sistema, mais próximo estarão dos valores das quantidades de bits que passam por cada ERB.

\subsection{Preparação do ambiente}

Para efeito de simulação, uma região foi dividida em um formato de $80 \times 80$, com 6400 microáreas. No intuito de formar um cluster ${ }^{1}$ de células, um total de 9 ERBs foram "instaladas" nas seguintes coordenadas (coluna,linha):

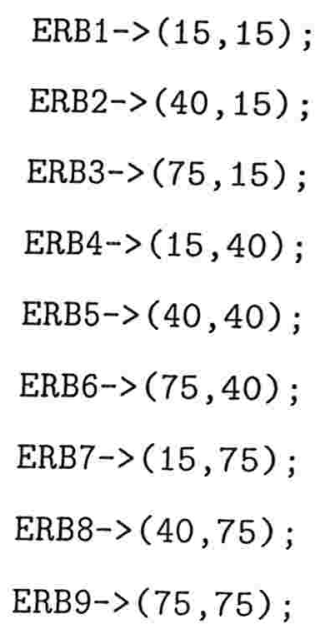

\footnotetext{
${ }^{1}$ Conjunto de células que podem se repetir em outra região, com as mesmas características, dentro da área total.
} 
A escolha das coordenadas das ERBs é proveniente de uma configuração que oferece de $30 \%$ a $45 \%$ de área de intersecção entre células [12], micro-áreas nesta região possuem sinal de mais de uma ERB. Além disso, em nenhum ponto existe uma micro-área sem sinal.

Cada ERB possui uma classificação que representa o perfil espacial do modelo de mobilidade adotado. A configuração adotada é:

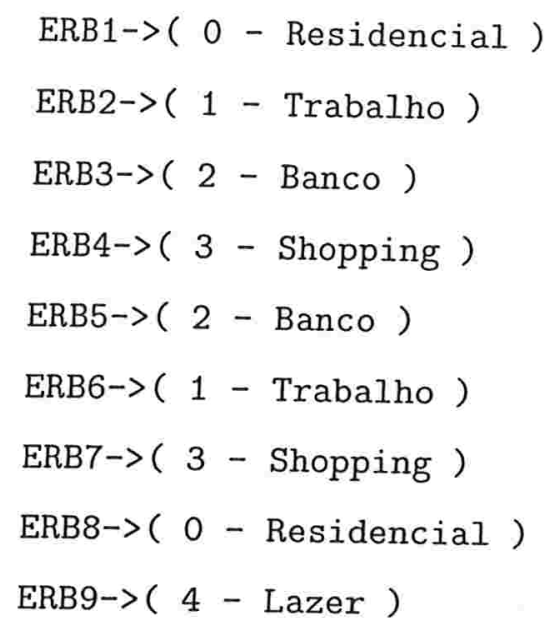

Toda UM é programada para ficar conectada durante o período de 24 horas, entretanto podem ocorrer desconexões desta unidade durante este período. Neste caso, a UM enquanto está se movimentando realiza requisições de conexão até que consiga se conectar novamente ao sistema. Isto é dimensionado para que possamos avaliar a utilização máxima do sistema, em termos do tempo conectado. Além disso, supomos que toda UM que estiver conectada no sistema, transmite dados a uma velocidade de 1 Kbps.

\subsection{Parâmetros de configuração da simulação}

Para verificar o comportamento das estratégias em diversas situações, foi necessário configurar o simulador sob diversos aspectos. A seguir estão os parâmetros utilizados nas simulações. São eles:

1. Quantidade de unidades móveis no sistema

Na simulação foi utilizado um total de 9 ERBs, sendo que cada ERB possui 30 canais disponíveis. Assim, o sistema disponibiliza um total de 270 canais para serem compartilhados por todas as unidades. Este parâmetro foi estabelecido para possibilitar a análise dentro de vários níveis de uso do sistema. A Tabela 8.1 mostra a quantidade de unidades utilizadas na simulação. 


\begin{tabular}{|c|c|c|c|}
\hline Item & Quantidade & Item & Quantidade \\
\hline 1 & 25 & & \\
\hline 2 & 50 & & \\
\hline 3 & 75 & & \\
\hline 4 & 100 & & \\
\hline 5 & 125 & & \\
\hline 6 & 150 & & \\
\hline 7 & 175 & & \\
\hline 8 & 200 & & \\
\hline 9 & 225 & & \\
\hline 10 & 250 & & \\
\hline 11 & 275 & & \\
\hline 12 & 300 & & \\
\hline
\end{tabular}

Tabela 8.1. Quantidades de UMs no sistema.

\section{Estratégias avaliadas}

Mais um ponto a ser considerado é a aplicação individual das estratégias relatadas no capítulo 5. A Tabela 8.2 menciona as estratégias empregadas.

\begin{tabular}{|c|l|}
\hline Item & Estratégia \\
\hline 1 & UM a mais tempo parada \\
\hline 2 & ERB com menor carga \\
\hline 3 & Rodízio de ERBs \\
\hline
\end{tabular}

Tabela 8.2. Estratégias empregadas.

3. Percentuais de carga de atuação

São as faixas percentuais de carga ${ }^{2}$ da ERB (inicial-final), onde serão aplicadas as estratégias. Este parâmetro é utilizado para se encontrar os percentuais referentes ao balanceamento permanente e crítico. A Tabela 8.3 mostra as faixas percentuais de atuação.

\footnotetext{
${ }^{2}$ Entende-se como carga de uma ERB, a quantidade de unidades conectadas a ela. Sendo $100 \%$ de carga equivalente ao uso de todos canais.
} 


\begin{tabular}{|c|c||c|c|}
\hline Faixa & Percentuais & Faixa & Percentuais \\
\hline 1 & 5 a $100 \%$ & 6 & 60 a $100 \%$ \\
\hline 2 & 20 a $100 \%$ & 7 & 70 a $100 \%$ \\
\hline 3 & 30 a $100 \%$ & 8 & 80 a $100 \%$ \\
\hline 4 & 40 a $100 \%$ & 9 & 90 a $100 \%$ \\
\hline 5 & 50 a $100 \%$ & 10 & 100 a $100 \%$ \\
\hline
\end{tabular}

Tabela 8.3. Faixas de percentuais de atuação.

\section{Eventos geradores}

Para o uso das estratégias não basta apenas que estejamos dentro da faixa percentual de carga determinada, é necessário também um evento que ative seu início. No entanto, os eventos também são causadores das alterações de carga da ERB.

A Tabela 8.4 mostra os 2 eventos geradores utilizados nesta simulação. Conforme visto na Figura 2.5 na página 11, a recusa de uma destas leva a conexão a não se manter do início ao fim desejado pelo usuário. Principalmente, se considerarmos que uma conexão ativa, idealmente, não deveria ser interrompida sem o consentimento do usuário.

\begin{tabular}{|c|l|}
\hline Item & Evento gerador \\
\hline 1 & Requisição de hand-off \\
\hline 2 & $\begin{array}{l}\text { Requisição de hand-off, ou } \\
\text { Requisão de conexão }\end{array}$ \\
\hline
\end{tabular}

Tabela 8.4. Eventos geradores.

\section{A constante $K$}

No capítulo 5 página 31 , é apresentado um limiar de transferência de carga, que basicamente faz com que os testes do tipo $\operatorname{carga}(E R B e)<\operatorname{carga}(E R B a)$ sejam substituidos por $\operatorname{carga}(E R B e)+K<\operatorname{carga}(E R B a)$. Esta constante pode ser utilizada para todos os algoritmos apresentados.

No intuito de se evitar distribuições desnecessárias, é preciso estabelecer um valor mínimo para $K$. 
As simulações mostraram que era conveniente utilizar o valor mínimo igual 2, entretanto as considerações necessárias para obter este valor serão expressas somente na análise de resultados. $\mathrm{Na}$ análise dos resultados também é apresentado o comportamento referente a alteração deste valor.

Todas simulações apresentadas utilizaram o valor de $K=2$.

Em $[9,37]$ são estabelecidos que quando a população das amostras não é conhecida, exige-se pelo menos 30 amostras, para que se possa extrair um intervalo de confiança, a fim de garantir $95 \%$ de certeza nos resultados (média das amostras). Ou seja, que em 100 conjuntos com o mesmo número de amostras, 95 deles apresentarão os valores da média dentro do intervalo de confiança.

Desta forma, para cada combinação das Tabelas 8.1, 8.2, 8.3 e 8.4 são realizadas 31 simulações, onde são calculadas as médias com o intuito de se obter os valores para avaliação.

\subsection{Avaliação dos resultados}

Nesta seção apresentamos os resultados e as análises das simulações, no entanto para efeito de apresentação, nós vamos dividí-los em duas fases: Definição dos percentuais de balanceamento e Diferenciação das estratégias.

\subsubsection{Definição dos percentuais de balanceamento}

Nesta fase pretende-se descobrir as faixas percentuais referentes ao balanceamento permanente e crítico. Respectivamente, tomaremos como base dois parâmetros de avaliação: A quantidade de bits transmitidos segmentados por ERB, e os bloqueios de hand-off.

\section{Balanceamento permanente}

Com a quantidade de bits transmitidos segmentados por ERB é possível avaliar a distribuição de carga entre as ERBs, assim calculamos o desvio padrão da carga entre as 9 ERBs. Os gráficos da Figura 8.1 e 8.2 apresentam o comportamento da estratégia 3 combinada com o item 2 da Tabela 8.4 (eventos geradores). Podemos destacar que o comportamento das demais combinações são semelhantes, porém apresentam valores diferenciados para cada estratégia, os quais serão detalhados na próxima fase.

Na Figura 8.1, o comportamento abaixo de 70-100\% mantem os valores de desvio padrão abaixo da curva sem balanceamento de carga. Apesar do gráfico apresentar os resultados apenas para 


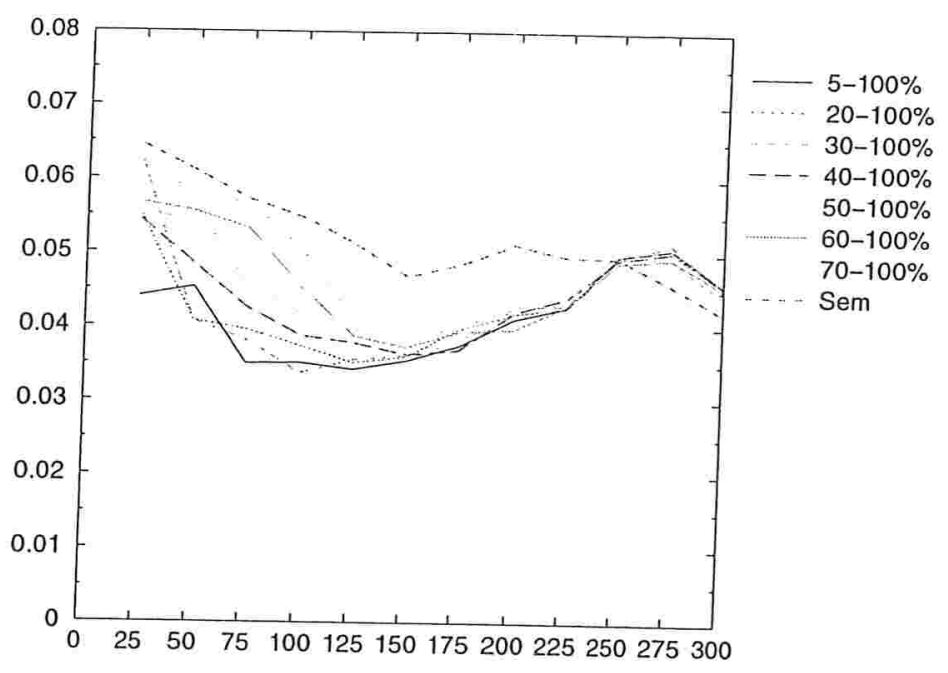

Figura 8.1. Gráfico das diferenças de desvio padrão de carga (5 a 70\%).

a estratégia 3, os resultados com as outras estratégias são semelhantes. A partir deste ponto, Figura 8.2, as diferenças não são tão significativas.

Devemos destacar que os valores dos desvios são considerados pequenos, no entanto se usarmos uma taxa de transmissão maior, como por exemplo de $14.4 \mathrm{Kbps}$ ao invés de $1 \mathrm{Kbps}$, as diferenças ficam mais significativas.

Outro ponto a discutir é que com mais de 250 unidades no sistema, a curva das estratégias tornam-se semelhantes a curva sem balanceamento, devido a saturação do sistema.

Esta evidência nos leva a deduzir que o balanceamento permanente é melhor utilizado na faixa dos 5 a $70 \%$.

\section{Balanceamento crítico}

Está relacionado principalmente ao objetivo de manter a conexão do início ao fim desejado pelo usuário. Para determinar as faixas percentuais de uso do balanceamento crítico vamos observar os valores dos "Bloqueios de hand-off", que é um dos motivos de não se alcançar este objetivo. A Tabela 8.5 apresenta os valores dos bloqueios.

Se forem utilizadas as estratégias nas faixas abaixo dos 100\% de carga, o que estaremos fazendo é prevenção de possíveis bloqueios. Isto pode levar a deduzir que existe um momento adequado de se realizar a prevenção. Ao observar a Tabela 8.5, as faixas abaixo da faixa $90-100 \%$ praticamente mantêm os mesmos índices da faixa $90-100 \%$, desta forma pode ser precoce realizar a prevenção dos bloqueios antes desta faixa, já que abaixo dela não há alteração significativa nos índices dos 


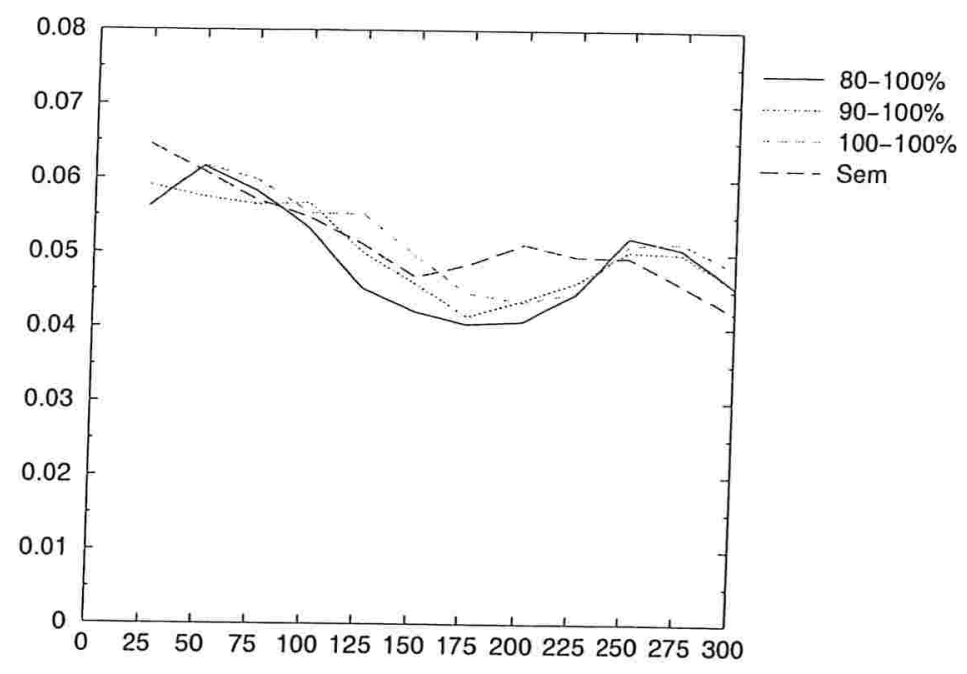

Figura 8.2. Gráfico das diferenças de desvio padrão de carga ( 80 a 100\%).

\begin{tabular}{|c|c|c|c|c|c|c|c|c|}
\hline Quant. UMs & $\ldots$ & $50-100 \%$ & $60-100 \%$ & $70-100 \%$ & $80-100 \%$ & $90-100 \%$ & $100-100 \%$ & Sem \\
\hline 25 & $\ldots$ & $0,00 \%$ & $0,00 \%$ & $0,00 \%$ & $0,00 \%$ & $0,00 \%$ & $0,00 \%$ & $0,00 \%$ \\
50 & $\ldots$ & $0,00 \%$ & $0,00 \%$ & $0,00 \%$ & $0,00 \%$ & $0,00 \%$ & $0,00 \%$ & $0,00 \%$ \\
75 & $\ldots$ & $0,00 \%$ & $0,00 \%$ & $0,00 \%$ & $0,00 \%$ & $0,00 \%$ & $0,00 \%$ & $0,01 \%$ \\
100 & $\ldots$ & $0,00 \%$ & $0,01 \%$ & $0,01 \%$ & $0,00 \%$ & $0,01 \%$ & $0,01 \%$ & $0,35 \%$ \\
125 & $\ldots$ & $0,07 \%$ & $0,09 \%$ & $0,07 \%$ & $0,09 \%$ & $0,10 \%$ & $0,09 \%$ & $1,71 \%$ \\
150 & $\ldots$ & $0,21 \%$ & $0,31 \%$ & $0,30 \%$ & $0,38 \%$ & $0,41 \%$ & $0,47 \%$ & $4,70 \%$ \\
175 & $\ldots$ & $0,60 \%$ & $0,61 \%$ & $0,65 \%$ & $0,86 \%$ & $0,90 \%$ & $1,06 \%$ & $8,58 \%$ \\
200 & $\ldots$ & $1,15 \%$ & $1,13 \%$ & $1,17 \%$ & $1,29 \%$ & $1,76 \%$ & $2,38 \%$ & $13,63 \%$ \\
225 & $\ldots$ & $2,78 \%$ & $2,78 \%$ & $2,81 \%$ & $2,96 \%$ & $3,27 \%$ & $5,14 \%$ & $18,84 \%$ \\
250 & $\ldots$ & $6,28 \%$ & $6,32 \%$ & $6,37 \%$ & $6,43 \%$ & $6,90 \%$ & $10,07 \%$ & $24,33 \%$ \\
275 & $\ldots$ & $12,59 \%$ & $12,59 \%$ & $12,41 \%$ & $12,71 \%$ & $13,64 \%$ & $17,42 \%$ & $30,49 \%$ \\
300 & $\ldots$ & $19,96 \%$ & $19,87 \%$ & $19,71 \%$ & $19,88 \%$ & $20,84 \%$ & $25,39 \%$ & $36,50 \%$ \\
\hline
\end{tabular}

\section{Tabela 8.5. Bloqueios de hand-off por faixa de carga}

bloqueios.

Sendo assim a faixa de 90-100\% é a mais adequada para uso do balanceamento crítico.

\section{Tráfego de controle}

A Figura 8.3 demonstra o tráfego adicional gerado pelo uso das estratégias.

$\mathrm{O}$ uso das estratégias implica em novos conjuntos de informações para controle. O principal fator de tráfego inserido no sistema, se aplica ao fato que ao realizar um balanceamento, as estratégias encaminham UMs para ERBs adjacentes através de requisições de hand-off. Cada evento gerador pode ocasionar apenas um encaminhamento para ERB adjacente, assim quanto antes começar o uso das estratégias, mais trafégo é inserido no sistema. Isto é visto na Figura 8.3.

Ao mesmo tempo quando uma UM é encaminhada via balanceamento para uma ERB adjacente, 


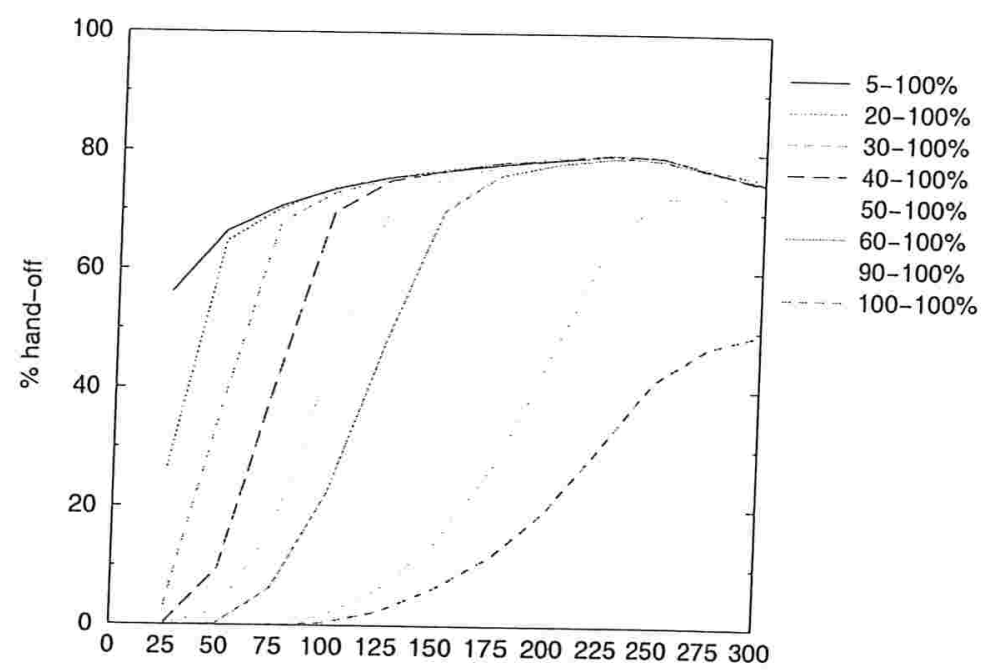

Figura 8.3. Tráfego adicional por Faixa de Carga (\% de hand-offs adicionais).

esta não provoca outro balanceamento na ERB adjacente, mesmo que tenha condições favoráveis para isto. O balanceamento só é ativado por eventos geradores não provenientes de outro balanceamento, isto foi feito para evitar um efeito cascata, o que poderia gerar um tráfego de controle adicional excessivo.

O hand-off demora um certo tempo para ser concluído, portanto não é desprezível, assim é indesejável contar com a realização imediata do hand-off. Com esta característica, ao utilizarmos as estratégias em 100\% de carga, não significa dizer que a ERB sem canais livres irá aplicar as estratégias, pois neste caso as requisições são recusadas. Na verdade, o que acontece é que no momento no qual a ERB tem um canal livre, e uma requisição de hand-off ou conexão é apresentada, a mesma é processada e logo após sua efetivação, as estratégias são solicitadas.

\subsubsection{Diferenciação das estratégias}

Nesta fase cada parâmetro de avaliação é analisado comparando as estratégias entre si e identificando as vantagens e desvantagens do seu uso. Para isso, o simulador foi configurado para realizar novas simulações dentro das faixas percentuais de balanceamento definidas na fase anterior (balanceamento permanente: 5-70\% ; balanceamento crítico: 90-100\%).

Entretanto, os resultados apresentados tratam das simulações envolvendo apenas o item 2 da Tabela 8.4 (eventos geradores), já que o item 1 da mesma tabela apresenta o mesmo comportamento, porém com os índices menos significativos. Isto é coerente com um de nossos trabalhos relacionados [8], onde é apresentado que com mesma prioridade tanto para novas conexões como 
para o hand-off, a capacidade do sistema é maximizada. Os resultados e análises estão a seguir:

\section{Bloqueios de hand-off}

A Tabela 8.6 apresenta dos índices dos bloqueios e respectivos intervalos de confiança.

\begin{tabular}{|l|ll|ll|ll|ll|}
\hline & \multicolumn{2}{|c|}{ Estratégia 1 } & \multicolumn{2}{c|}{ Estratégia 2 } & \multicolumn{2}{c|}{ Estratégia 3 } & \multicolumn{2}{c|}{ Sem Estratégia } \\
\hline \hline $\begin{array}{l}\text { Quant } \\
\text { UMs }\end{array}$ & Valor & $\begin{array}{l}\text { Intervalo } \\
\text { Confiança }\end{array}$ & Valor & $\begin{array}{l}\text { Intervalo } \\
\text { Confiança }\end{array}$ & Valor & $\begin{array}{l}\text { Intervalo } \\
\text { Confiança }\end{array}$ & Valor & Intervalo \\
Confiança \\
\hline \hline 25
\end{tabular}

Tabela 8.6. Bloqueios de hand-off com intervalos de confiança.

Ao observar os índices, nota-se que todas as estratégias apresentam bons resultados em relação ao não uso de balanceamento, em alguns casos chegando a $15 \%$ de redução.

As estratégias 2 e 3, considerando os intervalos de confiança, apresentam resultados tecnicamente iguais. A hipótese 3 da Seção 5.3, onde supõem-se que o direcionamento das UMs para ERBs adjacentes com menor carga poderia criar outros pontos com falta de balanceamento, não se concretizou, já que as estratégia 2 e 3 não apresentaram diferenças.

A estratégia 1 apresenta resultados inferiores as outras estratégias, entretanto apresenta bons resultados em relação a não utilização do balanceamento. Com isso, a hipótese 1 da Seção 5.3 é confirmada, desde que exista primeiramente a escolha da ERB adjacente, para depois se escolher dentre as unidades na intersecção com a ERB adjacente escolhida, a UM com menos mobilidade, o que acontece nas estrategias 2 e 3 . Aliás, escolher primeiramente a UM torna os índices de avaliação inferiores ao do que escolher primeiramente a ERB adjacente.

\section{Quantidade de bits transmitidos}

Se somarmos os bits transmitidos pelas UMs, considerando cada uma das 9 ERBs, teremos o total de bits transmitidos por todo sistema. Estes valores são apresentados pela Tabela 8.7, incluindo seus respectivos intervalos de confiança. 


\begin{tabular}{|c|c|c|c|c|c|c|c|c|}
\hline \multirow[b]{2}{*}{$\begin{array}{l}\text { Quant } \\
\text { UMs } \\
\end{array}$} & \multicolumn{2}{|c|}{ Estratégia 1} & \multicolumn{2}{|c|}{ Estratégia 2} & \multicolumn{2}{|c|}{ Estratégia 3} & \multicolumn{2}{|c|}{ Sem Estratégia } \\
\hline & Valor(Mb) & $\begin{array}{l}\text { Intervalo } \\
\text { Confiança }\end{array}$ & Valor (Mb) & $\begin{array}{l}\text { Intervalo } \\
\text { Confiança }\end{array}$ & Valor(Mb) & $\begin{array}{l}\text { Intervalo } \\
\text { Confiança }\end{array}$ & Valor(Mb) & $\begin{array}{l}\text { Intervalo } \\
\text { Confiança }\end{array}$ \\
\hline 25 & 2,160 & \pm 0.00 & 2,160 & \pm 0.00 & 2,160 & \pm 0.00 & 2,160 & \pm 0.00 \\
\hline 50 & 4,320 & \pm 0.00 & 4,320 & \pm 0.00 & 4,320 & \pm 0.00 & 4,320 & \pm 0.00 \\
\hline 75 & 6,480 & \pm 0.00 & 6,480 & \pm 0.00 & 6,480 & \pm 0.00 & 6,479 & \pm 1.06 \\
\hline 100 & 8,639 & \pm 1.54 & 8,639 & \pm 1.84 & 8,639 & \pm 0.78 & 8,604 & \pm 9.42 \\
\hline 125 & 10,779 & \pm 8.20 & 10,787 & \pm 5.52 & 10,784 & \pm 6.46 & 10,609 & \pm 22.69 \\
\hline 150 & 12,875 & \pm 16.97 & 12,873 & \pm 17.11 & 12,876 & \pm 20.38 & 12,369 & \pm 40.69 \\
\hline 175 & 14,849 & \pm 27.28 & 14,895 & \pm 24.69 & 14,884 & \pm 29.97 & 14,007 & \pm 42.93 \\
\hline 200 & 16,735 & \pm 40.65 & 16,794 & \pm 30.37 & 16,787 & \pm 35.06 & 15,355 & \pm 39.40 \\
\hline 225 & 18,409 & \pm 51.45 & 18,461 & \pm 50.54 & 18,501 & \pm 45.01 & 16,649 & \pm 59.77 \\
\hline 250 & 19,629 & \pm 64.60 & 19,741 & \pm 53.00 & 19,771 & \pm 58.78 & 17,658 & \pm 76.55 \\
\hline 275 & 20,435 & \pm 54.46 & 20,543 & \pm 76.57 & 20,503 & \pm 48.34 & 18,619 & \pm 62.37 \\
\hline 300 & 20,982 & \pm 55.40 & 21,069 & \pm 44.65 & 21,065 & \pm 53.54 & 19,266 & \pm 65.87 \\
\hline
\end{tabular}

Tabela 8.7. Quantidade de bits transmitidos com intervalos de confiança.

Ao observarmos os índices notamos que todas as estratégias apresentam bons resultados em relação ao não uso de balanceamento, em alguns casos chegando a $2 G b$ a mais. Neste caso $2 G b$ corresponde a $11,97 \%$.

As estratégias 2 e 3 , considerando os intervalos de confiança, apresentam resultados tecnicamente iguais. Entretanto a estratégia 3 possui uma leve tendência de vantagem até 250 unidades no sistema, a partir deste ponto esta tendência muda, e fica a favor da estratégia 2.

A análise deste parâmetro de avaliação é muito semelhante ao parâmetro anterior, pois o comportamento dos mesmos são semelhantes, o que era de se esperar, visto que quanto maior o índice de bloqueio de hand-offs, mais unidades são desconectadas do sistema, portanto menos bits transmitidos.

\section{Quantidade de novas conexões no sistema}

Em uma situação ideal, nesta simulação cada UM deveria ficar conectada durante as 24 horas. Portanto a quantidade de novas conexões deveria ser o mesmo da quantidade de UMs no sistema. Infelizmente, ocorrem desconexões causadas por falhas nas requisições de hand-off, logo as UMs desconectadas ficam solicitando novas conexões até serem re-admitidas ao sistema.

O gráfico apresentado pela Figura 8.4 mostra a quantidade de novas conexões no sistema.

A curva que representa a não utilização de balanceamento, apresenta as maiores quantidades de novas conexões, o que não significa ser um bom resultado, já que o ideal seria que as novas conexões fossem iguais a quantidade de UMs no sistema. A característica desta curva é devido ao fato que o índice de bloqueio de hand-off ser superior do que as curvas das estratégias. Pois com um índice 


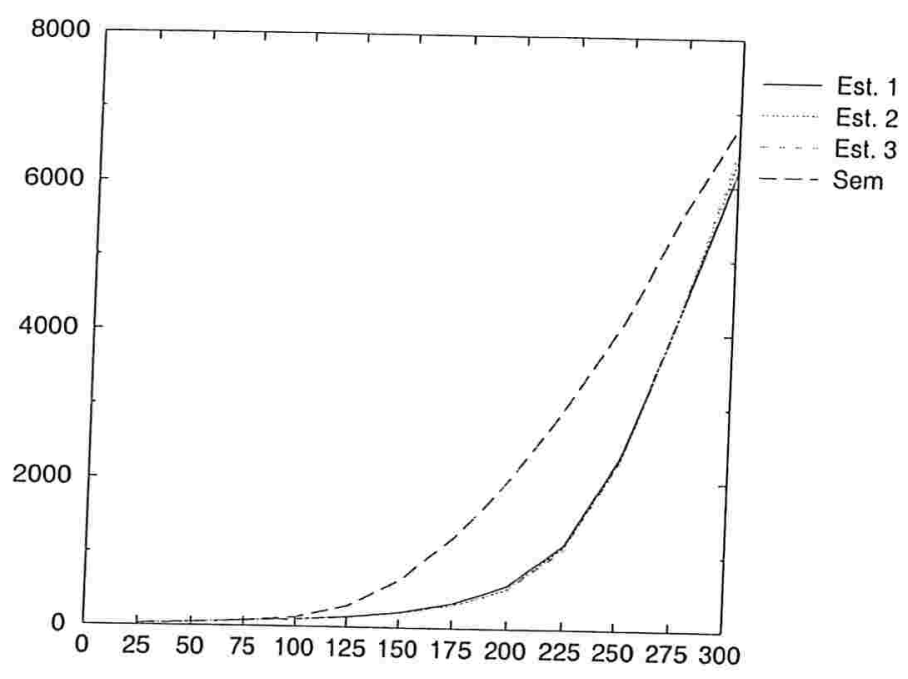

Figura 8.4. Quantidade de novas conexões no sistema.

maior de bloqueio, ocorre um maior número de desconexões, consequentemente maior número de novas conexões.

Apesar de não estar visualmente aparente no gráfico, as curvas das estratégias apresentam o mesmo comportamento que nos parâmetros anteriores.

\section{Tráfego de controle}

A Figura 8.5 apresenta o tráfego de controle adicional gerado pelas requisições de hand-off originadas pelas estratégias de balanceamento. O comportamento das curvas das estratégias são semelhantes. Apresentam uma "depressão" entre 150 e 225 UMs no sistema, proveniente do intervalo entre o balanceamento permanente e crítico, faixa entre $70-90 \%$.

A estratégia 1 apresenta os menores valores de tráfego, o que é coerente com sua menor eficiência nos bloqueios de hand-off, pois distribui um número menor de UMs provenientes dos balanceamentos. As demais estratégias apresentam valores tecnicamente iguais. Aliás, a não utilização de estratégias não insere tráfego adicional.

\section{A constante $K$}

Foram relizadas várias simulações com valores menores e maiores do que o valor mínimo adotado. Todas simulações desta dissertação foram realizadas com $K=2$. No entanto, foram realizados testes com valores de $K<2$, para verificar a validade do valor mínimo de $K$. Os resultados mostraram que os índices não sofreram alteração em relação ao valor de $K=2$, exceto no caso do tráfego 


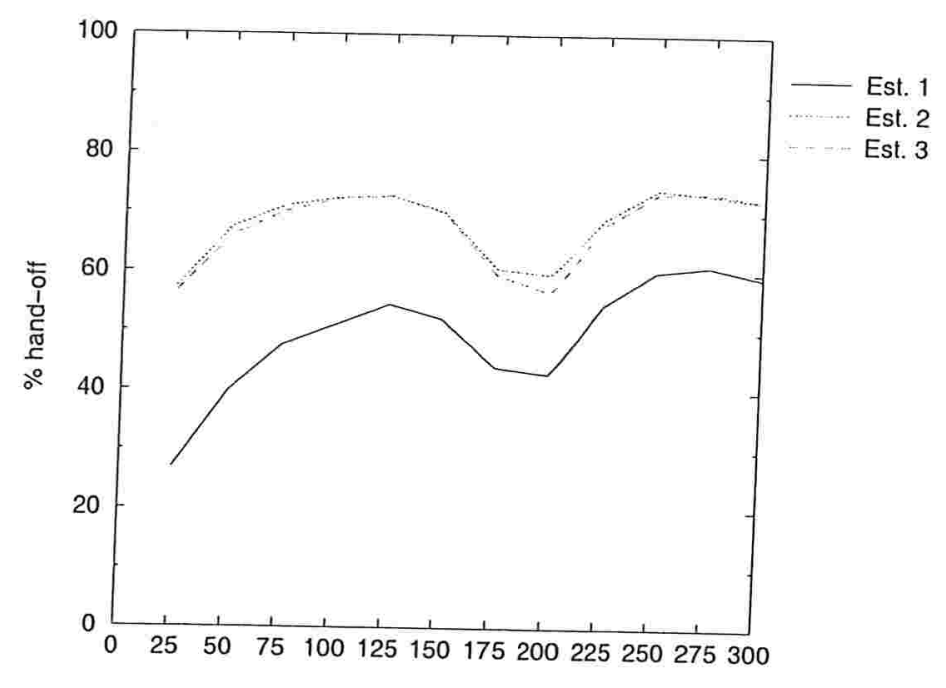

Figura 8.5. Tráfego adicional (\%hand-offs adicionais).

que sofreu um acréscimo, assim o uso das estratégias com o valor de $K$ abaixo de 2, só revelam desvantagens.

Com relação aos valores de $K$ superiores a 2, as simulações apresentaram comportamentos semelhantes aos apresentados com valor igual a 2. Entretanto, quanto maior for o valor de $K$ menor é o tráfego inserido no sistema. Além disso, conforme o valor de $K$ aumenta, os demais parâmetros vão se aproximando dos valores que representam a não utilização de balanceamento, até o ponto onde se tornam iguais.

\section{Outras Simulações}

Nas simulações apresentadas foram utilizadas um total de 9 ERBs, no entanto para esclarecer se um número maior de ERBs no sistema poderia interferir nas estratégias, foi realizada algumas simulações utilizando 25 ERBs, com as mesmas características, porém utilizando uma maior área geográfica (134 x 134 micro-áreas).

Os resultados apresentados demonstraram que não houve alteração no comportamento das estratégias, nesse novo ambiente. O que torna o uso das estratégias indiferente ao tamanho da área de cobertura.

\subsubsection{Análise final}

As estatégias 2 e 3 são tecnicamente iguais, elas apresentam valores semelhantes em todos os parâmetros analisados. Além disso, elas apresentam os melhores índices, tanto em relação a es- 
tratégia 1 como em relação a não utilização de balanceamento de carga.

Com relação aos eventos geradores é conveniente que tanto as requisições de hand-off como a requisições de novas conexões ativem as estratégias, maximizando desta forma a capacidade do sistema.

O incoveniente das estratégias é o número de hand-offs adicionais inseridos no sistema. Pois o custo de atualizações geradas pelo hand-off nas camadas altas (acima da camada de rede do modelo ISO) em alguns sistemas podem ser bastante relevantes. Portanto nestes casos, talvez possa ser conveniente utilizar a estratégia 1, que insere uma quantidade menor tráfego no sistema. Outro fator que pode ajudar a diminuir este custo adicional, é o parâmetro da "constante $K$ ". $K$ inicialmente foi definida com valor mínimo de 2 , entretanto o aumento deste valor provoca uma diminuição do tráfego adicional, isso em detrimento dos outros índices. Em casos extremos pode se optar pela não utilização do balanceamento permanente ficando apenas com o balanceamento crítico.

\subsection{Principais dificuldades e experiências adquiridas}

Durante a realização desta dissertação muitas dificuldades surgiram pelo caminho, dentre as dificuldades apresentadas vamos destacar principalmente a implementação do simulador, e a análise dos resultados.

$\mathrm{Na}$ implementação do simulador, as primeiras propostas baseavam na utilização de um simulador para computação móvel, entretanto conforme motivos detalhados na Seção 7.1 decidiu-se pela implementação própria do simulador.

Inicialmente o simulador foi desenvolvido sem utilização de programação concorrente, a qual está implementada na versão final do simulador. A construção da versão final do simulador apresentou vários aspectos que deveriam ser tratados, a fim de realizar uma simulação coerente com a realidade. Estes aspectos tornaram o desenvolvimento muito mais complicado do que a própria implementação das estratégias propostas, e em muitas vezes nos levaram a pensar em rever os motivos pela construção própria do simulador. Talvez rever o simulador $N s$ de forma mais profunda poderia aliviar os problemas apresentados. Entretanto a experiência adquirida no desenvolvimento de software com programação concorrente, torna a escolha válida em vários aspectos. Além disso, as considerações na implementação nos levaram adaptações nas estratégias, para se obter melhores resultados. Outro ponto a considerar foi a experiência na implementação de sistemas distribuídos e o aprendizado com a linguagem Java. 
Outra dificuldade bastante relevante foi a realização e análise das simulações, principalmente se considerarmos a quantidade de resultados gerados, assim como simulações realizadas.

Para cada configuração foram realizadas 31 simulações, e cada configuração é uma combinação das Tabelas 8.1, 8.2, 8.3 e 8.4. Assim para encontrar os percentuais de balanceamento foi necessário realizar a quantidade de simulações apresentada pela Tabela 8.8.

\begin{tabular}{|cccccccccc|}
\hline \multirow{2}{*}{ Repetições } & \multicolumn{2}{c}{ Itens } & \multicolumn{2}{c}{ Itens } & \multicolumn{2}{c}{ Itens } & \multicolumn{2}{c|}{ Itens } & Total \\
& & Tabela & 8.1 & & Tabela & 8.2 & Tabela 8.3 & Tabela 8.4 & simulações \\
\hline \hline 31 & $\mathrm{x}$ & 12 & $\mathrm{x}$ & 3 & $\mathrm{x}$ & 10 & $\mathrm{x}$ & 2 & $=$ \\
\hline
\end{tabular}

Tabela 8.8. Quantidade total de simulações

Já para visualizar as diferenças entre as estratégias foi necessário um total de 3348 simulações, pois já estavam definidos os percentuais de balanceamento, portanto sem a necessidade de realizar as simulações com a Tabela 8.3 (faixas percentuais). Além destas simulações, muitas outras foram realizadas para se testar o simulador e também para se obter algumas respostas sobre questões como: a interferência da constante $K$ no sistema; se a quantidade de ERBs no sistema não interfiriria nos resultados das estratégias; se o balanceamento poderia ser causado, ou não, por um evento gerador proveniente de outro balanceamento; dentre outras questões.

A grande maioria das simulações foram realizadas no Laboratório de Computação Paralela e Distribuída (LCPD), onde seus 6 computadores são dotados de processadores Pentium II 400Mhz e sistema operacional Linux Debian. Dentro deste ambiente, cada lote ${ }^{3}$ de combinação das tabelas de parâmetros de configuração demorava em torno de 4 a 6 horas de processamento até seu término. Além disso, as simulações deveriam ser realizadas fora do período usual, para que não prejudicassem as operações dos demais usuários do laboratório. Para acelerar a coleta de dados, a simulação foi distribuída em 6 computadores do laboratório, mesmo assim, a coleta de dados se decorreu por um bom período de tempo.

Diversas informações são coletadas em cada simulação, com isso muitos gráficos e tabelas foram gerados para as análises, o que promoveu uma análise cuidadosa e demorada. Mas, que ao final confirmaram as expectativas iniciais da dissertação, assim como atenderam aos objetivos propostos.

\footnotetext{
${ }^{3}$ Cada lote é composto pela combinação das Tabelas 8.1, 8.2 e 8.4, os demais parâmetros eram configurados um a um em cada lote
} 


\section{Capítulo 9}

\section{Considerações finais}

Com a evolução das comunicações móveis, grande parte das regiões metropolitanas do Brasil e do Mundo, já possuem tecnologias instaladas para atender este serviço, muitas vezes com o utilização mais de uma tecnologia de comunicação (TDMA, CDMA, GSM), apesar que na grande maioria utilizam a infra-estrutura basicamente para comunicação de voz.

Neste trabalho foram apresentadas várias alternativas para políticas de hand-off que consideram as áreas de intersecção entre as coberturas de ERBs que compõe a área de cobertura de uma região geográfica. Estas alternativas estão baseadas no fato de um hand-off poder ser iniciado por uma base, e não apenas devido a mobilidade das UMs. Com o uso desta nova possibilidade, pode-se distribuir melhor as UMs entre as ERBs, consequentemente oferecendo um novo grau de liberdade com relação a alocação de canais. Através das simulações apresentadas, mostramos os benefícios e os problemas que podem ser obtidos com a utilização deste novo grau de liberdade.

A utilização das propostas desta dissertação abrem novas possibilidades, tanto em aspectos relacionados aos usuários como em aspectos ligados as operadoras do serviço de comunicação móvel.

Sob os aspectos relacionados aos usuários, o uso das estratégias possibilitam uma maior chance de uma conexão ser mantida do início ao fim desejado pelo usuário, sem que existam interrupções da comunicação. Assim chegando de forma mais próxima aos recursos oferecidos pela computação tradicional. Por outro lado, elas elevam a quantidade de hand-offs, que apesar de serem transparentes aos usuários, podem gerar implicações em alguns sistemas utilizados pelo usuário. Cabe às operadores do serviço dimensionarem sua infra-estrutura, com o objetivo de obterem a melhor relação custo/benefício.

Sob os aspectos das operadoras do serviços de comunicação móvel, o uso das estratégias promovem 
um melhor balanceamento de carga entre as estações base de rádio. Deste modo, a infra-estrutura associada as ERBs, antes possivelmente sobrecarregada, trabalhariam com carga mais homogênea em relação as ERBs adjacentes. O uso das propostas diminui os índices de bloqueios de hand-off, desta forma as operadoras podem dimensionar sua estrutura para atender um número maior de unidades móveis, sem o comprometimento dos índices oferecidos atualmente. Do mesmo modo que os hand-offs adicionais gerados pelas estratégias podem oferecer implicações aos usuários, a infra-estrutura do sistema de comunicação também pode sofrer implicações.

Outro fator interessante está relacionado a implantação das estratégias de balanceamento na prática. A utilização das propostas não necessariamente significa a mudança de equipamentos, na verdade são necessários apenas a atualização de software na infra-estrutura das ERBs, e em alguns casos atualização dos drives das unidades móveis. O sistema de comunicação móvel também pode trabalhar tanto com ERBs que utilizam as propostas, como ERBs sem este processo. Assim, a implantação pode ser gradativa, sem prejuízos ao andamento das operações atuais.

Uma das perspectivas futuras é a realização de adaptações em um protocolo de comunicação, para que forneça as informações necessárias para o uso das estratégias. Informações como a atualização do nó negro (grafo de adjacência) de uma unidade móvel na ERB, indicando a região de intersecção onde a unidade está localizada. Ainda temos a solicitação de informação de carga das ERBs, dentre outras.

Finalmente, o problema de balanceamento de carga entre áreas de intersecção foi bem estudado nesta dissertação. Evidentemente, existem vantagens e desvantagens para o sistema. Entretanto, pode ser utilizada uma configuração que estabeleça a relação custo/benefício conveniente. 


\section{Apêndice A}

\section{Diagrama de Classes}

Neste apêndice é apresentado o diagrama de classes do simulador, a documentação completa das classes pode ser encontrada em www.lcpd.ime.usp.br/ santiago/aloca/index.html. 


\begin{tabular}{|l|}
\hline \multicolumn{1}{|c|}{$\begin{array}{r}\text { Frame } \\
\text { Constantes }\end{array}$} \\
\hline $\begin{array}{l}\text { simula } \\
+ \text { simula } \\
+ \text { paint:void } \\
+ \text { AchouNoPreto:boolean } \\
+ \text { FilasVazias:boolean }\end{array}$ \\
\hline +mainivoid \\
\hline
\end{tabular}

\begin{tabular}{|l|l|}
\hline $\begin{array}{r}\text { Object } \\
\text { Constances } \\
\text { microarea }\end{array}$ \\
\hline $\begin{array}{l}\text { +microarea } \\
\text { +Adderb:void } \\
\text { +Erbmaiorsinal:erb } \\
\text { +Nivelerb:int }\end{array}$ \\
\hline
\end{tabular}

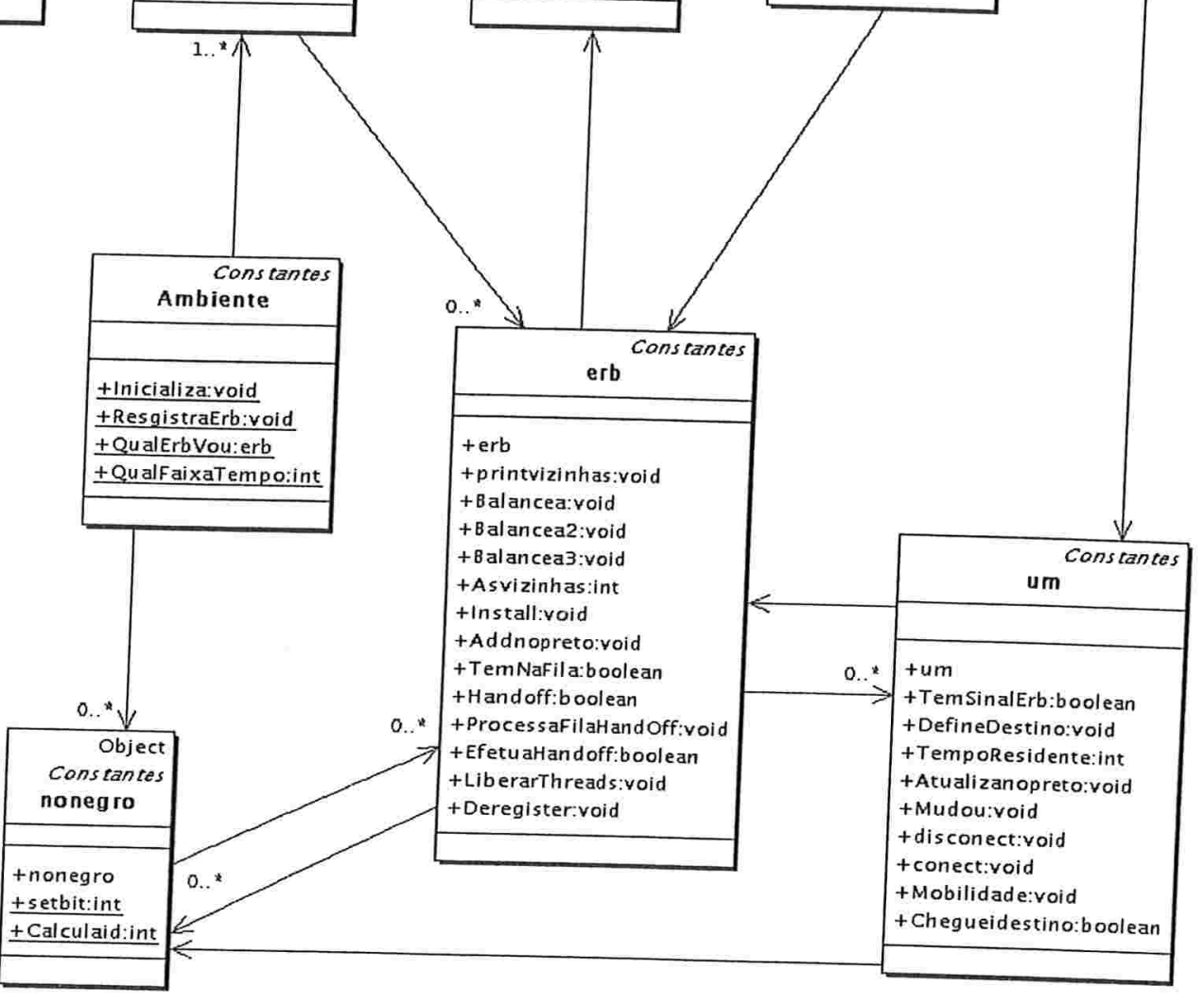




\section{Referências Bibliográficas}

[1] J. Abril, F. Comellas, A. Cortés, J. Ozón, and M. Vaquer. A multiagent system for frequency assignment in cellular radio networks. IEEE Transactions on Vehicular Techonology, 49(5):1558-1565, Sep 2000.

[2] B. Alencar. Um modelo de mobilidade de usuários para redes de comunicação móvel celular. Master's thesis, Centro de Informática UFPE, Março 1999.

[3] R. Bagrodia, R. Meyer, and M. Takai. Parsec: A parallel simulation environment for complex systems. IEEE Computer, 31(10):77-85, Oct 1998.

[4] A. Boukerche, K. Sajal, A. Fabbri, and O. Yildiz. Exploiting model independence for parallel PCS network simulation. In 13th Workshop pn Parallel and Distributed Simulation(PADS 99), volume 1, pages 166-173, Atlanta, GA USA, May 1999.

[5] L. Breslau, D. Estrin, K. Fall, S. Floyd, J. Heidmann, A. Heimy, P. Huang, S. McCanne, K. Varadhan, Y. Xu, and H. Yu. Advances in network simulation. IEEE Computer, 5(33):5967, May 2000.

[6] D.A. Cavalcanti, K.L. Dias, and D. Sadok. Estudos dos aspectos de qos e mobilidade no planejamento de uma rede móvel celular. In I WorkShop de sistemas de informações distribuídas de agentes móveis, volume 1, pages 125-140, Outubro 2000.

[7] D.A. Cavalcanti, J. Kelner, and D. Sadok. Variações temporais e espaciais na alocação de canais em um sistema celular. In Anais IXX SBRC 2001, volume 1, pages 120-129, Florianópolis SC, Maio 2001.

[8] J.W. Chang and D.K. Sung. Adaptive channel reservation scheme for soft handoff in DS-CDMA cellular systems. IEEE Transactions on Vehicular Technology, 50(2):341-353, Mar 2001. 
[9] S. Costa. Introdução ilustrada à Estatística, chapter 12. Harbra, 1998.

[10] G. Dahn, K. Jornsten, G. Lovnes, and S. Svaet. Graph optimization problems in connection with the managment of mobile communication systems. Telecomunication Systems, 3:319-339, 1995.

[11] K.L. Dias, J.C. Oliveira, D. Souza, and D. Sadok. Uma arquitetura para análise de carga de sinalização em redes de comunicaçao móvel celular. II Workshop de Comunicação sem fio, 1(2):10-16, 2000.

[12] D. Everit. Traffic capacity of cellular mobile communications systems. Computer Networks ISDN Systems, 20:447-454, 1990.

[13] A. Farago. On the complexity of finding sparsest and densest parts in wireless networks. Wireless NetWorks, 1(1):221-235, 1995.

[14] G.H. Forman and J. Zahorjan. The challenges of mobile computing. IEEE Computer, 27(6):3847, Apr 1994.

[15] T. Fujii and S. Nishioka. Selective handover for traffic balance in mobile communications. In IEEE/Supercomm/ICC 92, volume 4, pages 1840-1846, 1992.

[16] VINT group. The network simulator - ns-2. Web Page. Available at: www.isi.edu/nsman/ns.

[17] P.L. Hiew and M. Zukerman. Efficiency comparison of channel allocation schemes for digital mobile communication networks. IEEE Transation on Vehicular Technology, 49(3):724-733, May 2000.

[18] L. Hu. Distribuited code assigments for CDMA packed radio networks. IEEE/ACM Transactions on Networking, 1:536-547, 1993.

[19] I. Katzela and M. Naghsshineh. Channel assigment schemes for cellular mobile telecomunication systems. IEEE Personal Communications Magazine, 3:10-31, Jun 1996.

[20] J.H. Lee, T.H. Jung, S.U. Yoon, S.K. Youm, and C.H. Kang. An adaptive resource allocation mechanism including fast and reliable handoff in ip-based 3 Gwireless networks. IEEE Personal Comunications, 1:42-47, Dez 2000. 
[21] W. Li and A.S. Alfa. Channel reservation for handoff calls in PCS network. IEEE Transation on Vehicular Technology, 49(1):95-104, Jan 2000.

[22] L.M. Liljenstam and R. Ayani. Mobsim++: An environment for parallel simulation of pcns. In SCS World Congress on Systens Simulation(WCSS 97), Singapore, Sep 1997. Society for Computer Simulation (SCS).

[23] J.G. Markoulidakis, G.L. Lyberopoulos, D.F. Tsirkas, and E.D. Sykas. Mobility modeling in third-generation mobile telecommunications systems. IEEE Personal Communications Magazine, pages 41-56, Aug 1997.

[24] G.R. Mateus and A.A. Loureiro. Introdução à Computação Móvel. 11a Escola de Computação, Rio de Janeiro, RJ, Julho 1998.

[25] J. K. Ousterhout. Tcl and the Tk Toolkit. Addisson-Wesley, 1994.

[26] UCLA PCL. GloMoSim - global mobile information systems simulation library. Web Page. Available at: pcl.cs.ucla.edu/projects/glomosim.

[27] F.D. Priscoli and F. Sestini. Fixed and adaptative blocking thresholds in CDMA networks. IEEE Personal Commumications, 5:123-131, Apr 1998.

[28] R.A. Rocha. Uma arquitetura para simulação flexível de protocolos para computação móvel. Master's thesis, IME - Universidade de São Paulo, São Paulo - SP, Abril 2001.

[29] M.E. Rodriges. Telefonia celular. Master's thesis, Departamento de Engenharia Elétrica PUCRIO, 2000.

[30] R.M. Salles. Protocolos de múltiplo acesso para redes sem fio. Master's thesis, Instituto Militar de Tecnologia, 1998.

[31] A. Santiago and A. Goldman. Políticas de hand-off com balanceamento de carga para computação móvel. III Workshop de Comunicação sem fio e Computação Móvel, 1(3):40-45, Agosto 2001.

[32] S.M. Shin, C.H. Cho, and D.K. Sung. Interference-based channel assigment for DS-CDMA cellular systens. IEEE Transactions Vehicular Technology, 48:233-239, Jan 1999. 
[33] D.H. Smith, S. Hurley, and S.M. Allen. A new lower bound for the channel assignment problem. IEEE Transactions on Vehicular Technology, 49(4):1265-1272, Jul 2000.

[34] Sun. Java version 1.4.01. Web Page. Available at: www.sun.com.

[35] S. Tekinay and B. Jabbari. A measurement-based priorization scheme for handovers in mobile cellular networks. IEEE Journal on selected Areas in Communications, 10(8):1343-1350, Oct 1992.

[36] TIA/EIA Interim Standards(IS-95). Mobile station - Base station compatibility standards for dual-mode wideband spread spectrum cellular systems, Jul 1993.

[37] R. Wonnacott and T. Wonnacoot. Introductory Statistics, chapter 8. John Wiley e Sons, 1985.

[38] X. Wu, K.L. Yeung, and J. Hu. Efficient channel borrowing strategy for real-time services in multimedia wireless networks. IEEE Transactions on Vehicular Techonology, 49(4):1273-1284, Jul 2000.

[39] X.Zeng, R. Bagrodia, and M. Gerla. Glomosim: A library for parallel simulation of largescale wireless network. In 12th Workshop pn Parallel and Distributed Simulation (PADS 98), volume 1, pages 154-161, Los Alamitos, May 1998. IEEE Computer Society. 